\title{
Sacrifice, Atonement, and Legal Ethics
}

\section{David Sweet}

There is no moral authority like that of sacrifice.

-Nadine Gordimer ${ }^{1}$

\section{INTRODUCTION}

Lawyers surely understand sacrifice. The business of representation requires a willingness to subjugate, at least temporarily, one's own priorities, beliefs, and comforts to those of another. Today, that willingness is tested and demanded with unprecedented force. Corporate litigators toil around the clock to perfect their clients' cases. Public defenders stagger under the heaviest caseloads their mandate and conviction will permit. In nearly every legal market, heightened competition has tipped the balance of power toward clients and caused practitioners to surrender more of their autonomy and time.

Examined more closely, however, the increasingly routine actions of attorneys are only sacrifices in a certain sense of the word-they are the exchange of one thing for something else. Corporate lawyers are richly compensated. The public defender's reward is in a different but no less valuable currency. In either case, the aggregate benefits that accrue to the lawyer roughly compensate her for her costs. This is a truism of the rational-actor school of economics, ${ }^{2}$ and there is no reason to suppose it does not generally prevail.

There is another brand of sacrifice, less common but equally familiar, perfected by American litigators of the last century: the representation of a worthy but unpopular cause or group. John Quincy Adams was an early

1. Nadine Gordimer, The Essential Gesture: Writing, POlitics and Places 294 (Stephen Clingman ed., 1988).

2. See, e.g., RICHARD A. POSNER, ECONOMIC ANALYSIS OF LAW $\$ \S 1.1-.4$ (6th ed. 2003); Thomas S. Ulen, Rational Choice Theory in Law and Economics, in 1 ENCYCLOPEDIA OF LAW AND ECONOMICS 790 (Boudewijn Bouckaert \& Gerrit De Geest eds., 2000). 
exemplar; ${ }^{3}$ Clarence Darrow, ${ }^{4}$ Charles Houston, ${ }^{5}$ and others belong in the same category. But note that each of these names is well-known to us. Many of them were famous before their landmark efforts, but in no case-and this seems generally true of lawyers who take similar stands-were their careers damaged or derailed by their "sacrifice." The notoriety of an unpopular case, successfully defended, redounds to the defender at least in magnitude. Then, as popular opinion catches up to the moral or legal vanguard, the pioneers are vindicated, lionized, and ultimately rewarded.

None of this is meant to demean the actions, accomplishments, or intentions of either everyday or exemplary lawyers. Those who do good, be it good work or good works, should be rewarded. ${ }^{6}$ Besides, the willingness to act on another's behalf, whatever the expected reward, requires at least a modicum of humility. Most poignantly, the civil society in which we now live testifies to the worthy sacrifices that lawyers as a class of professionals have made.

But these sacrifices, although critical to our understanding of what a lawyer is and should be, are not the type that I propose to discuss here. The incentives to work harder for a client, or to take on a worthy cause, are well established and well understood. Such sacrifices are rational and, above all, they are human - the kind of sacrifice in which I am interested is arguably not. My subject is vicarious sacrifice, the relinquishment by one person of a right or good for the sole benefit of someone else. Within that category, I focus on substitutionary sacrifice-the imposition of oneself in the place of another. More specifically still, this Note examines the voluntary assumption by one person of the cost or penalty attributable to the other.

With this last qualification, I touch on another concept generically familiar to lawyers-atonement. In its most colloquial sense, atonement simply means repayment, and as such, the law customarily demands atonement for its breach-through compensatory damage awards, for example. ${ }^{7}$ There is, however, a deeper and more technical understanding of

3. See, e.g., HOWARD JONES, MUTINY ON THE AMISTAD: THE SAGA OF A SLAVE REVOLT AND ITS IMPACT ON AMERICAN ABOLITION, LAW, AND DIPLOMACY 175-94 (rev. ed. 1988) (describing Adams's argument of the Amistad case before the Supreme Court).

4. See, e.g., Hal Higdon, Leopold AND LoEB: THE CRIME of THE CENTURY 188-274 (1999) (describing Darrow's defense of Leopold and Loeb).

5. See, e.g., RICHARD KLUGER, SIMPLE JUSTICE: THE HISTORY OF BROWN $v$. BOARD OF EDUCATION AND BLACK AMERICA'S STRUGGLE FOR EQUALITY 147-205 (1976) (describing Houston's involvement with the NAACP's legal campaign to end segregation).

6. The aphorist Mason Cooley once quipped, "Self-sacrifice usually contains an unspoken demand for payment." The Columbia World of Quotations No. 13,630 (Robert Andrews et al. eds., 1996), http://www.bartleby.com/66/30/13630.html. We need not be so harsh. There is an important difference between "unspoken demands" and reasonable expectations.

7. See, e.g., In re Pier, 561 N.W.2d 297, 302 (S.D. 1997) ("Repayment alone will not establish rehabilitation, but certainly restitution expresses the sincerest form of atonement and the surest mark of accountability." (emphasis added)). Not all legal remedies involve this type of 
the word. Theologians and religious ethicists have defined atonement as a complex process encompassing some or all of repentance, apology, reparation, penance, and forgiveness. ${ }^{8}$. The goal toward which this progression aims is not merely the repayment of an outstanding debt, but the complete restoration of the preexisting relationship. Accordingly, atonement demands a willingness from the injured and the injurer to recognize both the harm that has been caused and the sufficiency of the remedy. It ultimately seeks to blot out the existence-and all recollection of the existence-of the injury. ${ }^{9}$

Several legal commentators have examined the theological doctrine of atonement and applied it to various legal fields, most frequently and naturally in the area of criminal justice and the study of alternative modes of punishment. ${ }^{10}$ In each case, the version of atonement the scholar adopts requires that the wrongdoer initiate and participate in the atonement process. Indeed, this is the prevailing approach of the law. Justice and economics suggest we should extract the repayment from the one who has perpetrated the harm. ${ }^{11}$

I do not intend to challenge that approach as a general matter. It is not, however, the model I propose to investigate here. The atonement that interests me is the payment by one person of a debt or penalty attributable to another. Stated more precisely, it is the vicarious and substitutional

atonement. Punitive damages and incarceration, for example, are not repayments but simply punishments. Specific performance and other expectation-based remedies are arguably hybrids between atonement and punishment.

8. See Richard SWINBURNE, RESPONSIBILITY AND ATONEMENT 81 (1989) ("Atonement involves four components-repentance, apology, reparation, and what, for want of a better word, I shall call penance (though not all of these are always required)."). See generally ANSELM OF CANTERBURY, Cur Deus Homo, in THE MAJOR WORKS 284-86 (Brian Davies \& G.R. Evans eds. \& Janet Fairweather et al. trans., 1998) (c. 1098) (developing the "satisfaction" theory of Christ's atonement). Anselm's version has dominated both Catholic and Protestant theology for hundreds of years; recently, however, there has been a resurgence in atonement theories that deemphasize the violence implicit in satisfaction atonement in favor of pacifist, feminist, and womanist understandings of the doctrine. See, e.g., J. DENNy WEAVER, THE NONVIOLENT ATONEMENT (2001).

9. Cf. Jeremiah 31:34 (New International Version) ("“I will forgive their wickedness and will remember their sins no more,' [declares the Lord]."); Psalms 103:12 (New International Version) ("[A]s far as the east is from the west, so far has he removed our transgressions from us."). The citation of Scripture here is meant to remind the reader that, although my arguments will be secular, the origins and underlying values of atonement are inescapably religious, and particularly strong in the Hebraic tradition. This connection-and the religious roots of secular professional ethics generally - should be acknowledged, appreciated, and explored. See infra Section I.A.

10. See, e.g., Stephen P. Garvey, Punishment as Atonement, 46 UCLA L. REV. 1801 (1999); cf. Samuel J. Levine, Teshuva: A Look at Repentance, Forgiveness and Atonement in Jewish Law and Philosophy and American Legal Thought, 27 FORDHAM URB. L.J. 1677 (2000) (analyzing the relevance for contemporary American law of Jewish teachings on teshuva, or repentance); Jeffrey C. Tuomala, Christ's Atonement as the Model for Civil Justice, 38 AM. J. JURIS. 221, 222-24 (1993) (exploring "parallels ... between the four principal views of Christ's atonement and currently debated theories of civil justice").

11. Criminal law enacts this belief most clearly. For a general discussion of an economic approach to crime, see POSNER, supra note $2, \S \S 7.1-.11$. 
sacrifice by one person of her rights or goods to atone for the harm caused or debt owed by another. This description is sufficiently technical; it is not necessary for the purposes of this Note to describe fully a detailed and dogmatic version of either sacrifice or atonement. Unlike the commentators referred to above, I am not interested in systematically applying a specific doctrine to a particular field of law.

Instead, this Note seeks simply to introduce to the scholarship on legal ethics a previously foreign idea: vicarious sacrificial atonement, ${ }^{12}$ a theological concept I apply here to mean the satisfaction by lawyers personally of the penalties imposed as a result of their clients' violation of procedural rules during the course of litigation. ${ }^{13}$ I suggest that an ethic of vicarious sacrificial atonement is both a viable and a valuable aspirational norm toward which legal ethics should point. Viable because the core values served by vicarious sacrificial atonement correspond closely to those privileged by our secular. legal system. Valuable because such acts of atonement, even if only isolated-even if only contemplated-could benefit the legal profession in at least three plausible and practical ways: by increasing the social and professional respect accorded to lawyers; by restoring client counseling as the focus of the attorney-client relationship; and by chilling client misbehavior, thereby strengthening the justice system for all players.

Rather than venture further into already deep water, I take a step back in Part I to examine briefly the origins and underlying values of vicarious sacrificial atonement. In Part II, I analyze a familiar ethical dilemma to determine the extent to which these concepts and values are currently embodied in the codes and norms of legal ethics. Finally, in Part III, I present in more detail some of the values, goals, and criticisms of the aspirational model alluded to above.

A caveat at the outset is in order. A full treatment of this subject is well beyond the scope of this Note and my ability. The concepts herein are drawn from philosophy, psychology, civics, religion, and many other fields (including the practice of law) in which I have no expertise. I want only to introduce the idea of vicarious sacrificial atonement in order to start a

12. I regret that this phrase-which appears throughout the Note-is so cumbersome. Although I may occasionally refer to the concept as simply "atonement" or by some other variant, each of the three words conveys an important piece of the working idea, and all are necessary for its proper expression.

13. My focus on procedural and not substantive violations is both intentional and essential to the theories of this Note. I do not propose, for example, that a defense attorney be incarcerated for his client's theft conviction. Instead, my concern is with procedural violations that a client commits while being represented by counsel. The distinction is not one of seriousness, as procedural sins such as perjury and obstruction may have severe consequences, but rather one of context. 
conversation among scholars with credentials better suited than mine to develop the rudimentary thoughts presented here.

\section{VICARIOUS SACRIFICIAL ATONEMENT}

Although the idea of vicarious sacrificial atonement is generally familiar, its application to the professional realm is unusual and perhaps uncomfortable. Like many religious concepts, it seems ill at ease in the secular world; more than others, it suggests an ancient, bloody, and ignorant history that is easily dismissed. But the religious roots of vicarious sacrificial atonement do not invalidate its application to secular ethical analysis. This is particularly true in the field of American legal ethics, which emerged in the early nineteenth century out of a broader religious revival. ${ }^{14}$ That movement sought to infuse civic duties with the sort of religious sanctimony appropriate to a country believed to be God's new promised land. At the same time, the newly independent nation was growing increasingly proud of its legal system, which became a vehicle for the ethical ambitions of religious and political reformers alike. The professional rules that eventually emerged from this environment formed the basis for twentieth-century codes, through which they still exercise influence today.

We live in an era in which the Hebraic roots of legal ethics are largely obscured, and it is inappropriate to evaluate the governing rules on religious terms they may no longer recognize. The impact and implementation of those rules, however, continues to be colored by the religious beliefs (whether present or absent) of the individual practitioners on whom they operate. ${ }^{15}$ Where the codes leave room for discretion, in rush whole worldviews. This influence is not only inescapable, but also desirable, for in many cases ethical requirements necessarily devolve to appeals to conscience. In such cases, we hope that individual consciences have been exposed to a breadth of influences from among which they can formulate thoughtful and satisfying conclusions and decisions. ${ }^{16}$

14. The two acknowledged pioneers of American legal ethics were deeply religious men. David Hoffman, who produced the first code of legal ethics in this country, was a serious Bible scholar. Judge George Sharswood was a staunch Presbyterian whose lectures on ethics formed the basis for the canons published by the American Bar Association in the early twentieth century. See THOMAS L. SHAFFER, ON BEING A CHRISTIAN AND A LAWYER: LAW FOR THE INNOCENT 59 (1981); THOMAS L. SHAFFER WITH MARY M. SHAFFER, AMERICAN LAWYERS AND THEIR COMMUNITIES 196(1991).

15. For a particularly fine example of the depth of insight a personal religious belief can bring to questions of law and legal ethics, see JAMES A. PIKE, BEYOND THE LAW (1963).

16. Although we all may not seek, as did Karl Barth, "the theological answer to the ethical question," KARL BARTH, ETHICS 50 (Dietrich Braun ed. \& Geoffrey W. Bromley trans., 1981), religion remains perhaps the most important ethical input for the majority of the American population that participates regularly in organized religious services. 
The influence of religion also operates more broadly than within the individual conscience. As William Simon writes, "[m]any private moral perspectives, religious and not, converge with public ones. The private perspective may inspire and motivate people to participate in the public realm. And it may offer insights that can be translated and incorporated into public discourse." 17 Professor Simon expresses the hope of this Note-that an intensely private perspective may offer applicable insights to those who may not share its deepest ideological foundations. Those foundations, even if not shared by the reader, are important to an understanding of the discussion to come.

\section{A. The Origins of Vicarious Sacrificial Atonement}

The practice of sacrifice is believed to be as old as human society itself. $^{18}$ Archaeological evidence dates the convention to at least the Paleolithic Age, and there are incidences in almost every major organized religion. ${ }^{19}$ Sacrifice is a deep-seated human response to the fears and mysteries of the world and, although modern conventions have tended to replace acts of physical sacrifice with symbolic gestures meant to recall them, the basic dynamic continues to occupy a central position in many faiths. The purpose of the rite varies slightly from tradition to tradition but may generally be characterized as an attempt to enter, maintain, or restore "a mystic beneficial relationship with the supramundane sources of providential bounty." 20 Of these goals, the restorative, or atoning, aspect of the practice is both the most familiar and the most important for our purposes. ${ }^{21}$ The Old Testament, for example, is replete with examples of propitiatory animal sacrifices made to an offended, distant, or threatening God. ${ }^{22}$ These acts were provisional,

17. William H. Simon, The Legal and the Ethical in Legal Ethics: A Brief Rejoinder to Comments on The Practice of Justice, 51 STAN. L. REV. 991, 1001 (1999).

18. For a comprehensive and canonical survey of the practice, see E.O. JAMES, SACRIFICE AND SACrament (1962). See also ROBERT J. Daly, Christian SaCrifice: THE JudaeoCHRISTIAN BACKGROUND BEFORE ORIGEN (1978) (providing further depth into the study of the Christian sacrament).

19. The rite is attenuated in some Eastern sects and has disappeared completely from Jainism, but these traditions are somewhat more recent developments within established religions that historically have practiced sacrifice. See JAMES, supra note 17 , at 47.

20. Id. at 20 .

21. One example of a nonrestorative sacrifice is Abel's offering of the fruits of his labors, made to maintain a beneficial relationship with God. See Genesis 4:2-4 (New International Version).

22. Examples of propitiatory sacrifices abound in other traditions as well. One such instance is Agamemnon's sacrifice of his daughter Iphigenia to appease the goddess Artemis prior to his sailing for Troy. See EuRIPIDES, IPHIGENIA IN AUlis (F. Melian Stawell trans., G. Bell \& Sons Ltd. 1929). 
deontological, and backward-looking-wrongs had been committed, and sacrifice was required to put them right.

Christianity is unique among major religions in that an act of sacrificial atonement occupies both the sacramental and the theological center of its belief structure. Given its historical influence on American legal ethics, Christianity is also uniquely important to our investigation, and as such a few extra words are warranted. Of greatest significance is Christianity's reversal of the traditional sacerdotal roles-Christians believe that God offered Himself as a sacrifice to restore a right relationship between a holy God and a wayward human race. According to that belief, Christ's death and resurrection perfected the regular animal sacrifices that God had previously demanded of the Jews and made full atonement for the sins not only of that people but of the entire world as well. As such, Christ's act was one of vicarious sacrificial atonement-not provisional but permanent, not only deontological but also teleological, not only backward-looking but also prospective and, indeed, eternal. ${ }^{23}$

\section{B. The Characteristics of Vicarious Sacrificial Atonement}

The origins of vicarious sacrificial atonement illuminate the moral characteristics associated with the practice. ${ }^{24}$ Although many of these characteristics-which might be called values-are discussed more pointedly below, ${ }^{25}$ they bear mentioning here. The characteristics may be separated into two categories: those that are inherent in acts of vicarious sacrificial atonement, and those that arise as a consequence of such acts. Perhaps the most obvious item in the former category is the selflessness displayed by the subject of the atonement-that is, the person sacrificing herself for another. ${ }^{26}$ That subject, who must hold herself of sufficient value to be an efficacious and meaningful sacrifice, nonetheless must account the good of the other greater than her own good-she must love the other more than she loves herself. ${ }^{27}$ This accounting is motivated by the second

23. These assertions are not wholly uncontroversial among theologians, but they are widely accepted and have been applied in a similar context before. See Garvey, supra note 10, at 1805-06.

24. By "moral characteristics" I mean those that are associated with the actors themselves, rather than systemic values like "justice" and "wholeness."

25. See infra Section III.A.

26. The distinction here between subject and object is complicated but important to my later discussion of lawyer independence. See infra Subsection III.C.2. By positing the person being sacrificed as the subject and not the object of the atoning act, I mean to emphasize the proactive nature of vicarious sacrifice, which in fact requires a willingness to negate one's own subjectivity.

27. This is hardly a universal value, either in our own day or in times past. Aristotle, for one, considered and dismissed the idea that self-sacrifice is to be preferred over self-love. See ARISTOTLE, 9 THE NICOMACHEAN ETHICS 234-37 (David Ross trans., 1954) (arguing that "the good man should be a lover of self"). The only "sacrifices" Aristotle commends are those that redound to "the greater good" of the one making the sacrifice. Such actions are not sacrifices in 
inherent characteristic of vicarious sacrificial atonement, namely compassion - the ability to "suffer with" the object of atonement. The one sacrificing herself must feel compelled to do so by the hurt resulting from the wrongs of the one for whom she makes the sacrifice. Without compassion, her self-sacrifice will be a random act that lacks the meaningful intentionality necessary to satisfy the wrong or debt. Compassion is itself only made possible by the third moral characteristic inherent in vicarious sacrificial atonement, namely the ability of the subject to identify with the other. Identification requires that the subject and object share at least one personal trait-their common humanity, for example-or, to put it another way, that they each participate in a community defined at least in part by that trait. ${ }^{28}$

There is also a set of characteristics that arise as a consequence of acts of vicarious sacrificial atonement. The first is cohesion. The subject and object of the sacrifice are linked and drawn together through both the anticipation and the execution of the sacrificial act. This dynamic has important consequences for their current and future relationship, including the potential reduction of agency costs, an effect that is revisited briefly later in the Note. ${ }^{29}$ The second consequential characteristic is the esteem given to the one making the sacrifice. This is not an appropriate motive for making vicarious sacrificial atonement, but it is a natural result that determines the ultimate influence of the act and its actors on those who witness or learn of the sacrifice. The third consequential characteristic of vicarious sacrificial atonement-and it is one that flows out of the first two-is the moral authority conferred upon the person who has made the sacrifice. This is probably the most important trait for the purposes of this Note, and I discuss it at greater length below. ${ }^{30}$

\section{VICARIOUS SACRIFICIAL ATONEMENT AND PreVAiLing LEgAL ETHICS}

The characteristics and values of vicarious sacrificial atonement are broadly admired in the abstract, but the sacrificial acts from which they derive are rarely practiced in public life. When they are, as by Dr. Martin Luther King, Jr. during his crusade for civil rights, their practitioners are revered as nearly otherworldly exemplars of both public and private

the truest sense, but rather economic transactions into which any rational actor should enter given the opportunity. Id. at 236-37. See supra note 2 and accompanying text.

28. The idea of community is important to discussions of legal ethics and this Note in particular. See infra note 109. See generally SHAFFER WITH SHAFFER, supra note 14 (investigating the relationship between lawyers and their professional and personal communities).

29. See infra note 89.

30. See infra Section III.B. 
virtue. ${ }^{31}$ Why are public acts of vicarious sacrificial atonement so rare as to be aberrational, while similar private acts (as among members of a family) are relatively common? There are almost certainly many reasons, but two bear special mention. The first is that most public communities, usually defined broadly by such shared traits as geography or race, do not present as compelling a cause for sacrifice as, say, a threatening God or a suffering child. The second, and more important here, is that our civic obligations are primarily understood in terms of individual rights rather than communal goods. ${ }^{32}$ As such, those obligations are largely defined and circumscribed by the legal system that allocates and protects those rights, a system that displays several traits inimical to the practice of vicarious sacrificial atonement.

\section{A. A Case Study-What To Do with Perjured Testimony?}

Before critiquing the legal system's resistance to acts of vicarious sacrificial atonement, we should first understand the instances in which such acts might be appropriate and viable. I have defined vicarious sacrificial atonement as the satisfaction by lawyers personally of the penalties imposed as a result of their clients' violation of procedural rules during the course of litigation. The first requirement, then, is an instance of client misbehavior during the course of litigation. Professor Monroe Freedman gives a familiar and all-too-frequent example. I hope that a careful, casuistical analysis of the scenario will illuminate both the possibilities and the values of acts of vicarious sacrificial atonement.

But first, the facts:

Assume the following situation. Your client has been falsely accused of a robbery committed at 16th and $P$ Streets at 11:00 p.m. He tells you at first that at no time on the evening of the crime was he within six blocks of that location. However, you are able to persuade him that he must tell you the truth and that doing so will in no way prejudice him. He then reveals to you that he was at 15 th and $P$ Streets at 10:55 that evening, but that he was walking east,

31. In his life, death, and public ministry, Dr. King both practiced vicarious sacrificial atonement as a means to racial reconciliation and exhorted his followers to do the same. His speech and action evidenced both the inherent and consequential values of vicarious sacrificial atonement: selflessness, compassion, and identification; cohesion, esteem, and moral authority. For more on this aspect of Dr. King's theology and ministry, see JAMES WM. MCCLENDON, JR., BIOGRAPHY AS THEOLOGY 47-66 (new ed. 1990).

32. This is obviously an oversimplification of an impossibly complex and controversial claim, but at the least it seems safe to say that individualistic values of liberalism take precedence over communitarian values in several prominent understandings of our civic and legal order. See, e.g., JOHN RAWLS, A THEORY OF JUSTICE 3 (rev. ed. 1999) ("Each person possesses an inviolability founded on justice that even the welfare of society cannot override."). 
away from the scene of the crime, and that, by 11:00 p.m., he was six blocks away. At the trial, there are two prosecution witnesses. The first mistakenly, but with some degree of persuasiveness, identifies your client as the criminal. At that point the prosecution's case depends upon that single witness, who might or might not be believed. The second prosecution witness is an elderly woman who is somewhat nervous and who wears glasses. She testifies truthfully and accurately that she saw your client at 15 th and $P$ Streets at 10:55 p.m. She has corroborated the erroneous testimony of the first witness and made conviction extremely likely. However, on cross-examination her reliability is thrown into doubt through demonstration that she is easily confused and has poor eyesight. Thus, the corroboration has been eliminated, and doubt has been established in the minds of the jurors as to the prosecution's entire case.

The client then insists upon taking the stand in his own defense, not only to deny the erroneous evidence identifying him as the criminal, but also to deny the truthful, but highly damaging, testimony of the corroborating witness who placed him one block away from the intersection five minutes prior to the crime. Of course, if he tells the truth and thus verifies the corroborating witness, the jury will be more inclined to accept the inaccurate testimony of the principal witness, who specifically identified him as the criminal. ${ }^{33}$

Suppose at this point the attorney is able to secure a promise from her client to testify truthfully. Now play out the scene: The client takes the stand (and the oath to tell the truth), but upon direct examination reneges. on his promise and lies about his whereabouts the evening of the crime. What should the lawyer do?

\section{B. A Starting Point}

The American Bar Association's Model Rules of Professional Conduct serve as a starting point. Rule 3.3(a) prohibits the lawyer from "offer[ing] evidence that the lawyer knows to be false. If a lawyer, the lawyer's client, or a witness called by the lawyer, has offered material evidence and the lawyer comes to know of its falsity, the lawyer shall take reasonable remedial measures, including, if necessary, disclosure to the tribunal." 34 This is hardly a ringing call to disclose the perjured testimony-the text creeps toward the dreaded "disclosure to the tribunal," carving out room

33. MonRoE H. FREEdMAN, LAWYERS' ETHICS IN AN AdVERSARY SYSTEM 30-31 (1975).

34. MODEL RULES OF PROF'L CONDUCT R. 3.3(a)(3) (2002). 
for lawyerly discretion as it goes. Comment 10 to the Rule offers the following gloss:

Having offered material evidence in the belief that it was true, a lawyer may subsequently come to know that the evidence is false. Or, a lawyer may be surprised when the lawyer's client or another witness called by the lawyer offers testimony the lawyer knows to be false, either during the lawyer's direct examination or in response to cross-examination by the opposing lawyer. In such situations or if the lawyer knows of the falsity of testimony elicited from the client during a deposition, the lawyer must take reasonable remedial measures. In such situations, the advocate's proper course is to remonstrate with the client confidentially, advise the client of the lawyer's duty of candor to the tribunal and seek the client's cooperation with respect to the withdrawal or correction of the false statements or evidence. If that fails, the advocate must take further remedial action. If withdrawal from the representation is not permitted or will not undo the effect of the false evidence, the advocate must make such disclosure to the tribunal as is reasonably necessary to remedy the situation, even if doing so requires the lawyer to reveal information that otherwise would be protected by Rule 1.6 [governing attorney-client privilege]. It is for the tribunal then to determine what should be done-making a statement about the matter to the trier of fact, ordering a mistrial or perhaps nothing. ${ }^{35}$

This is helpful, but somewhat curious. The threshold question-when the lawyer must make disclosure-is obscured by the comment's explication of "reasonable remedial measures," which themselves ultimately seem to be only "such disclosure ... as is reasonably necessary to remedy the situation." This tautology aside, the gloss does at least help to order the attorney's steps: Most commentators agree that the remedy must first be sought from and with the client himself. ${ }^{36}$

35. Id. R. $3.3 \mathrm{cmt} .10$.

36. See People v. Johnson, 72 Cal. Rptr. 2d 805, 811-12 (Cal. Ct. App. 1998) ("All the legal commentators agree that when faced with a client who indicates he will commit perjury, an attorney should first attempt to persuade the client to testify truthfully."). It is not true that "all the legal commentators agree" about what should be done either prior to the perjury or afterwards. The more strident segment of the defense bar disputes that knowingly presenting perjured testimony is always wrong, and certainly disagrees that, the perjury having been committed, it must be disclosed to the court. See Abbe Smith \& William Montross, The Calling of Criminal Defense, 50 MERCER L. REV. 443, 526-27 (1999) ("[U]nder the framework of fidelity, it would be unethical for a defense attorney not to present a client's perjurious testimony or some other untruth, if the client insists upon it. It would be wrong for a criminal defense lawyer . . . to engage in any of the conduct often recommended for an attorney in the face of a client bent on presenting perjured testimony: disclosure to the court, withdrawal from the case, refusal to present the testimony, or refusal to comment on it." (emphasis added)). 
A more forceful directive is found in an ABA committee opinion stating that "[i]t is now mandatory, under [Model Rule 3.3(a) and 3.3(b)], for a lawyer who know[s] the client has committed perjury, to disclose this knowledge to the tribunal if the lawyer cannot persuade the client to rectify the perjury." 37 This approach is less ambiguous (assuming we can agree on what "perjury" means), but it begs the question why this "mandatory" disclosure requirement has not been written into the Code itself. It instead is two removes from the most authoritative text, which itself requires only "reasonable remedial measures, including, if necessary, disclosure to the tribunal." 38

One possible explanation is that the bar does not want mandatory disclosure. This is Professor Freedman's position, which we can infer from his analysis of the original hypothetical: "In my opinion, the attorney's obligation in such a situation would be to advise the client that the proposed testimony is unlawful, but to proceed in the normal fashion in presenting the testimony and arguing the case to the jury if the client makes the decision to go forward." ${ }^{, 39}$ This view is not uncontroversial, ${ }^{40}$ but I suspect that Freedman has simply articulated in theory what most defense lawyers would execute in practice.

It is important to see that a lawyer's failure to disclose her client's perjury cannot always be attributed to a craven disregard for the truth; it might often stem from a profound respect for it. The moment she perceives the lie, the attorney must choose between two truths: where her client was that night, and the trial outcome her client deserves. The first impulse may be to label these the "smaller" and "larger" truths of the scenario, respectively, but doing so answers prematurely the very question I would like to explore. Calling them the "proximate" and "ultimate" truths, respectively, is more useful for these purposes. ${ }^{41}$

How then to proceed? There are two approaches the attorney might employ to choose between the respective truths: a "truth-weighing" approach and a "truth-seeking" approach. I test these in that order now.

37. ABA Comm. on Prof'l Ethics and Grievances, Formal Op. 87-353 (1987), cited in Brian Slipakoff \& Roshini Thayaparan, Note, The Criminal Defense Attorney Facing Prospective Client Perjury, 15 GEO. J. LEGAL ETHICS 935, 949 n.119(2002).

38. MODEL RULES OF PROF'L CONDUCT R. 3.3(a)(3).

39. FREEDMAN, supra note 33, at 31 . For a helpful recent summary of both the shortcomings of the Model Rules' approach and the responses of other commentators to Professor Freedman's analysis, see Slipakoff \& Thayaparan, supra note 37.

40. For one prominent critique, see Marvin E. Frankel, The Search for Truth: An Umpireal View, 123 U. PA. L. REV. 1031 (1975). See also infra note 49. See generally William H. Simon, The Ethics of Criminal Defense, 91 MICH. L. REv. 1703 (1993) (critiquing the assumption that the "standard adversary ethic" is viable in criminal defense work even if too aggressive elsewhere).

41. Cf. REINHOLd NeIBUHR, THE IRONY OF AMERICAN History 120 (1952) ("[P]olitics deals with the proximate ends of life, and religion with ultimate ones ...."). 


\section{Weighing the Truths}

The first strategy is for the attorney to weigh methodically the proximate and ultimate truths to determine which one has greater aggregate value and thus deserves her allegiance. ${ }^{42}$ In doing so, she should consider the value of the truth to the four significant entities in the scenario: the truthful but discredited witness, the attorneys, the litigants, and the system as a whole. I begin with the proximate truth and its value to the truthful witness. In this scenario, the value of the proximate truth to the nearsighted elderly woman is measurable but small-there is not a significant social stigma to being elderly and nearsighted, and the witness has no substantial stake in seeing her testimony verified.

In some cases, however, the discredited truth-teller will have a much greater interest in not being thought of as a liar. ${ }^{43}$ Consider a sexual harassment civil suit that devolves to a credibility contest between the accused and his accuser. The charge is false (by which I mean legally unsustainable if all truths were known by the factfinder), but the litigants have a concealed sexual history that makes the accusation more plausible than it might be otherwise. The plaintiff raises this history on the stand and, against the private counsel and expectations of his attorney, the defendant lies to rebut and discredit it. His attorney remains quiet, and the jury returns the "right" result - a judgment in favor of the defendant. The ultimate truth has been served, but at the cost of a proximate truth that has appreciable value to a woman whose reputation has been unfairly tarnished.

The second group to which the disclosure of the proximate truth has value comprises the lawyers trying the case. The defense attorney whose client has lied has a duty to the truth as an officer of the court, and so the disclosure of the proximate truth has a value equal to the value she places on that duty. In addition, prompt disclosure of the proximate truth may insulate her from the risk of future disciplinary consequences for suborning perjury. The prosecuting attorney, on the other hand, values the proximate truth inasmuch as he does not want to be thought of as having proffered unreliable or false testimony, together with whatever desire he has not to be associated with a system that permits undisclosed false testimony.

The value of disclosure of the proximate truth to the litigants in the case is slim: The lying defendant has no stake in it, except for the value, which

42. One example of the weighing approach is William Simon's analysis of Paul Newman's mailbox larceny in the movie The Verdict, see WILLIAM H. SiMON, THE PRACTICE OF JUSTICE: A THEORY OF LAWYERS' ETHICS 100-01 (1998), and his subsequent defense of that analysis, see Simon, supra note 17 , at $997-98$.

43. The following variation is adapted from a real-life account given by defense attorney Kenneth Mann. See Kenneth Mann, Ethics in the Practice of Law, Lecture at Yale Law School (Oct. 17, 2002). 
he is likely to discount, of any moral rehabilitation resulting from being forced to confront and recant his false testimony. The prosecuting state has scarcely more interest in the disclosure of the proximate truth, and what value it does have is largely subsumed by its representative's personal stake, discussed above.

So far, it seems unnecessary for the defense attorney to disclose the fact that her client presented perjured testimony. But there is a fourth party to which the truth may have value, and that is the system that will survive a failure to disclose the lie. The first component of that value is theoretical, since a failure to disclose the proximate truth puts the lie to a central justification of the adversary system-that it is an effective truth-seeking mechanism. One implication of a refusal to disclose the proximate truth is that the court might not be able to reach the correct result (that is, the ultimate truth) if that proximate truth were revealed. Accordingly, the implication goes, the adversaries themselves must be the ones to filter or shape the "truth" that is presented to the factfinder. The second component of the value of the proximate truth to the system is political-the value of the public's perception of the court as a place of not only true outcomes, but truthfulness generally. The third and final component is the procedural value inherent in abiding by the accepted ethical codes and rules of procedure. This component raises larger questions of whether due process is served whenever the right result is achieved, even if it is achieved by procedurally or ethically dubious means.

Continuing with the weighing approach, the value of the proximate truth summarized above must be compared to the value of the ultimate truth - that the defendant is innocent of the crime charged. The value of this truth is more apparent than that of the proximate truth, and only a short summary is required here. The same four parties must be considered. The value of the ultimate truth to the truthful witness is not appreciably greater than the value that all laypeople share in having others' cases adjudicated correctly. In addition to the economic rewards of success, the value of the ultimate truth to the defense counsel is engendered through her role as the client's agent, as one who participates in the client's interest in a correct determination of innocence. Likewise, the prosecuting attorney, as an officer of the court, participates in the court's interest in reaching that same correct determination.

The value of the ultimate truth to the litigants is substantial and obvious. The defendant has a strong interest in not being convicted for something he did not do, including an interest in not being publicly shamed for legal behavior, while the state has a philosophical and practical stake in reaching the correct outcome dictated by the legality or illegality of the behavior in question. Finally, the value to the system is similarly clear. From a substantive perspective, the outcome is the most important thing, 
and there is political value in the public perception of the legal process as one that consistently reaches the right result.

Reviewing the analysis, the aggregate value of the ultimate truth in this particular hypothetical seems to outweigh significantly the aggregate value of the proximate truth. Under the weighing approach, then, defense counsel would be justified in withholding from the court the fact that his client committed perjury. This methodology, I believe, is roughly the process most practitioners would apply when faced with this scenario, and this is almost certainly the result at which they would arrive. It is difficult to imagine any defense lawyer jeopardizing his client's freedom (or future business) by reporting the perjury either during or after trial. Note, however, that the prevailing ethical rules, their interpretation by the courts, and the majority of the academic literature all reject a non-disclosure rule; instead, all advocate some form of post-perjury revelation. ${ }^{44}$

Regardless of what say the "scribes and teachers of the law," the weighing approach seems in this case to be straightforward and to produce a satisfactory result, at least within the context of the prevailing legal system from which the hypothetical is taken. Justice has been served, even if at the expense of truth, or more precisely, $a$ truth. But further thought on this result should leave us deeply unsatisfied. We should not be surprised that the consistent subjugation of lesser truths to just results would cultivate a professional ethic that increasingly undervalues those truths. Such is the case in our current system. Witness perjury, suborned or spontaneous, is endemic - so frequent in criminal cases that parties on both sides expect that witnesses will lie to the extent they cannot be debunked by the opposition. ${ }^{45}$ This suspicion has worked its way into our conception of a noholds-barred adversary system, but it is surely against both the original

44. There are notable exceptions to this position, of course, including Professor Freedman's. See supra notes 33, 39 and accompanying text; see also Smith \& Montross, supra note 36, at 526-27.

45. There is a general feeling that the rate of witness perjury is ever-increasing:

[J]udges and others insist that the anecdotal evidence of a growing frequency of perjury is overwhelming.

"It is much more serious a problem than most people believe," says V. Robert Payant, president of the National Judicial College in Reno, Nev. "For the last couple of years, we have been hearing this complaint from more and more of our judges. It's no longer a small twisting of the facts or a little white lie here or there. It's happening in almost every case."

Mark Curriden, The Lies Have It: Judges Maintain That Perjury Is on the Rise, but the Court System May Not Have Enough Resources To Stem the Tide, A.B.A. J., May 1995, at 68, 69, quoted in Manuel R. Ramos, Legal and Law School Malpractice: Confessions of a Lawyer's Lawyer and Law Professor, 57 OHIO ST. L.J. 863, 890 n.77 (1996). Notwithstanding the anecdotal suspicions of judges, there is no particular reason to believe that standards of truthfulness have decreased significantly over time. In any case, pervasive witness perjury has been of academic concern for nearly a century. See W.A. Purrington, The Frequency of Perjury, 8 ColuM. L. REV. 67 (1908); Alfred David Whitman, A Proposed Solution to the Problem of Perjury in Our Courts, 59 DICK. L. REV. 127, 127 (1955) ("Few crimes except fornication are more prevalent or carried off with greater impunity."). 
design and any rational version of that system. ${ }^{46}$ Why swear witnesses to the truth if not to expect it, and why persist in the practice if the oath has become a mockery? Given the erosion of truthfulness in our courts, ${ }^{47}$ it is worth at least investigating an approach to the hypothetical that pays more respect to all truths.

\section{Seeking the Truths}

A truth-seeking approach would try to satisfy the desire for truth to the greatest extent possible. The goal is to reach both truths of the clientperjury hypothetical - that the client is innocent, and that at the time of the crime he was not in fact where he claimed to be in his testimony. Note that this approach does not privilege one truth over another ex ante; therefore, it may yet please adversarial defense lawyers who have their clients' best interests in mind.

As an initial matter, because the defendant in this case is in fact innocent, his counsel should not interrupt the proceedings to challenge the proffered testimony or bring it to the attention of the court if doing so would jeopardize the correct outcome. ${ }^{48}$ Instead, disclosure of the perjury-thereby reaching the proximate truth-should happen after the verdict has been reached. How should such disclosure be effected? There seem to be two basic alternatives: The first is for the lawyer to do so in such a way that places responsibility for the perjury on the client; the second is for the lawyer to accept that responsibility himself. The former approach is advocated by the Model Rules, a majority of the academic literature, and the many courts that have considered the issue. ${ }^{49}$ It intuitively appeals to

46. But as some are quick to point out, the impulse toward perjury may be inherent in and encouraged by the adversarial nature of the system. Geoffrey Hazard is reported to have said: "Why do we expect people to be absolutely honest when their entire economic life or their freedom and liberty relies on it? ... Yes, shading the truth and telling lies occurs in almost every case, I am sure. But we have created this adversarial system that encourages it." Curriden, supra note 45 , at 69 . For further discussion of the tension between the adversary system and vicarious sacrificial atonement, see infra Subsection III.C.1.

47. Or simply the lack thereof-its rate of change is irrelevant here.

48. This initial decision is necessary to serve the ultimate truth, but it is vulnerable to several lines of criticism, including one focusing on questions of role fidelity and institutional competence. I attempt to respond to this critique below. See infra Subsection III.C.3.

49. For the treatment of the issue in the Model Rules, see supra notes 34-38 and accompanying text. Most (and perhaps all) state and federal courts have ruled on the issue. The U.S. Supreme Court, while denying its ability to promulgate ethical rules governing state court practice, has implicitly sided with lawyers by holding that a counsel's threat to withdraw from a case in the event of her client's perjury cannot give rise to an ineffective assistance of counsel claim. See Nix v. Whiteside, 475 U.S. 157 (1986). Nix is the leading case on an attomey's responsibilities in the face of client perjury, and it yields several observations that are relevant here. The first is the way in which the legal question was framed, not as "What should a lawyer do in the face of client perjury?" but rather as "Is it a violation of a client's constitutional rights for his lawyer to do this particular thing in the face of client perjury?" As a result, the Nix opinion is less a normative exploration of legal ethics than an attempt to define the boundaries of a 
our symmetrical sense of fairness - the client lied, the client should accept responsibility. As then-Judge Cardozo once aphorized, "The willful transgressor must accept the penalty of his transgression."

But symmetry has its costs. The drafters of the notes to the Model Rules recognize the serious consequences that even post-trial disclosures of client perjury may have:

The disclosure of a client's false testimony can result in grave consequences to the client, including not only a sense of betrayal but also loss of the case and perhaps a prosecution for perjury. But the alternative is that the lawyer cooperate in deceiving the court, thereby subverting the truth-finding process which the adversary system is designed to implement. Furthermore, unless it is clearly understood that the lawyer will act upon the duty to disclose the existence of false evidence, the client can simply reject the lawyer's advice to reveal the false evidence and insist that the lawyer keep silent. Thus the client could in effect coerce the lawyer into being a party to fraud on the court. ${ }^{51}$

What is needed is a disclosure that mitigates any sense of betrayal, protects the correct substantive outcome (the ultimate truth), and precludes

nonethical legal issue, namely, the standard for ineffective assistance of counsel set forth in Strickland v. Washington, 466 U.S. 668 (1985). See Nix, 475 U.S. at 172 ("We see this as a case in which the attomey successfully dissuaded the client from committing the crime of perjury.").

The four Justices concurring in the judgment (Blackmun, Brennan, Marshall, and Stevensall of whom had tended to favor expansion of defendants' rights) were not satisfied that the Court had limited its opinion to this latter, proper purpose, and wrote to clarify that "the Court's essay regarding what constitutes the correct response to a criminal client's suggestion that he will perjure himself is pure discourse without force of law." Id. at 177 (Brennan, J., concurring). They also wrote to preserve and protect a more flexible ethical regime in which "[t]he complex interaction of factors, which is likely to vary from case to case, makes inappropriate a blanket rule that defense attomeys must reveal, or threaten to reveal, a client's anticipated perjury to the court." Id. at 189 (Blackmun, J., concurring). This statement affirms the sort of "truth-weighing" methodology that I believe most practicing lawyers support and employ. See supra Section II.C.

The Court's analysis and holding, limited to the Strickland context, is likewise consistent with prevailing legal doctrine and is undoubtedly correct as a matter of law. Behavior in line with the stated ethical norms-regardless of the consistency with which those norms should be or actually are followed-hardly can give rise to a Strickland violation. But Nix reflects the prevailing legal and ethical regime in yet another way. The result in Nix underscores the reality that attorney withdrawal, as much as attorney reporting, puts responsibility for the perjury squarely on the client. This truth has attracted little or no notice in the voluminous academic literature that has responded to Nix and addressed the issue more generally. See Slipakoff \& Thayaparan, supra note 37 , at $937 \mathrm{n} .15$ (listing prominent articles). None of this literature-nor any ethical writing about the perjury hypothetical-suggests that the lawyer might assume any part of the blame for the client. Thomas Shaffer, who conducts an extensive analysis of the clientperjury scenario, somewhat surprisingly sides with Professor Freedman, concluding that the lie should not be revealed. Professor Shaffer's reasoning, to the extent that it focuses exclusively on the client at the expense of those hurt by the perjury, is arguably inconsistent with his communityesteeming approach elsewhere. See SHAFFER, supra note 14, at 93-104.

50. Jacob \& Youngs, Inc. v. Kent, 129 N.E. 889, 891 (N.Y. 1921).

51. MODEL RULES OF PROF'L CONDUCT R. $3.3 \mathrm{cmt}$. 11 (2002) (citation omitted). 
a prosecution for perjury. I assert that an act of vicarious sacrificial atonement-the assumption by the lawyer of the responsibility for her client's perjury - can accomplish all three, with the important caveat that each of these consequences of the act is ultimately beyond the attorney's control. $^{52}$

\section{E. Serving the Truth Through Vicarious Sacrificial Atonement}

Suppose, subsequent to a verdict of not guilty for her client, the victorious attorney were to disclose her client's perjury to the court and fully accept all responsibility for the violation, including expressing a willingness to bear whatever sanctions, censure, or other consequences would usually be attributable to the client. ${ }^{53}$ What would this accomplish? The first result, and one that is independent of the court's response, is to achieve the truth-seeking goal discussed earlier. The ultimate truth has been reached by the jury or judge; now the proximate truth has come out as well. Whatever the magnitude of the value we ascribe to that proximate truth, we surely believe that its disclosure, independent of consequences, is to be preferred over its concealment. We hope that such disclosure will reinforce the ethic of truthfulness on which we believe an ideal system of justice must be based; the interpretation and application of that ethic in this particular case is in the hands of the presiding judge. I examine this aspect of the scenario shortly.

A related result, also independent of the court's response, is the affirmation of the attorney's role as an "officer of the court." Although that title has been criticized as vague and misleading, ${ }^{54}$ and has been invoked in support of many different conceptions of the lawyerly role, ${ }^{55}$ I do not rely on any overly technical definition. Instead, I read the phrase as something akin to "officer of the truth," on the theory that the court is imagined, positioned, and expected to be the primary truth-seeker. ${ }^{56}$ In fact, a lawyer's

52. For a brief discussion of the court's possible reaction to such an act, see infra note 60 and accompanying text. For a more general discussion both of the barriers to acts of vicarious sacrificial atonement and of the proper response of an ethical actor in the face of such barriers, see infra Section III.C.

53. It is important for the aspirations of the ethical model that the attomey not herself lie; that is, she must make clear that although she did not suborn perjury and even counseled against it, she nonetheless is willing to accept responsibility for the act.

54. See, e.g., James A. Cohen, Lawyer Role, Agency Law, and the Characterization "Officer of the Court," 48 BUFF. L. REV. 349, 353 (2000); Eugene R. Gaetke, Lawyers as Officers of the Court, 42 VAND. L. REV. 39, 39 (1989).

55. See Cohen, supra note 54 , at 353 .

56. Cf. Nix v. Whiteside, 475 U.S. 157, 174 (1986) ("[T] $]$ he responsibility of an ethical lawyer, as an officer of the court and a key component of a system of justice, dedicated to a search for truth, is essentially the same whether the client announces an intention to bribe or threaten witnesses or jurors or to commit or procure perjury. No system of justice worthy of the name can tolerate a lesser standard."). 
fealty to the truth-and particularly here the proximate truth-applies a degree of moral and ethical pressure to the presiding judge, who herself may be reminded of her own duties in the service of both the proximate and the ultimate truth. In any case, by disclosing a truth that would otherwise remain concealed, the lawyer has discharged a portion of her duty toward the proper functioning of the adjudicatory process.

Before turning to the possible responses of the court to the attorney's act, a few words are called for regarding the act's effect on the attorney's relationship with her client. ${ }^{57}$ The commentators to the Model Rules are right to be concerned about betrayal-trust is the foundation of our greatest hopes for the ethical potential of the attorney-client relationship, and this potential is in turn one of the strongest arguments against simply reporting the client's perjury and assigning him the blame.

An ideal act of vicarious sacrificial atonement has two characteristics that should dampen the client's feelings of betrayal. The first is its congruence with the rest of the attorney-client relationship. The client must be able to locate and understand his counsel's sacrifice within the context of their prior and anticipated future dealings. Recall our earlier discussion of the inherent characteristics of vicarious sacrificial atonement. Necessary to the client's understanding is an appreciation of the lawyer's compassion for and identification with her client, values that should pervade the entire representation and not merely this single act. Accordingly, the sacrifice should follow pretrial counseling against perjury, which all commentators recommend, and a warning that the lawyer is prepared to make the sacrifice should her client persist in the lie. If this attention fails to prevent the perjury, the client can hardly then feel betrayed when the lawyer makes good on her "threat."

The second characteristic is self-evident-the act is, or is intended to be, atoning. If accepted by the court, the lawyer's sacrifice is fully substitutionary and removes the legal guilt and liability otherwise attributable to the client. ${ }^{58}$ This may trigger a range of responses by the beneficiary of such an act, but a feeling of betrayal — antithetical to the value of cohesion discussed earlier-should not be one of them.

Of course, the client's paramount objective in this case is not precisely the continued concealment of the proximate truth, but rather that disclosure of that truth not expose him to any liability. ${ }^{59}$ Much turns, then, on the

57. See infra Section III.B (discussing these issues within the context of a broader aspirational norm of vicarious sacrificial atonement).

58. The lawyer's sacrifice does publicly expose the defendant as a liar and thus subjects him to extralegal shame and sanction. The fullest expression of vicarious sacrificial atonement would include efforts by the lawyer to mitigate even this consequence, perhaps by requesting that the details of the client's infraction remain confidential.

59. Note that once the defendant has been acquitted of the original, substantive charge, the constitutional double jeopardy prohibition protects him from being retried on that charge, even if 
response of the court to the lawyer's act of vicarious sacrificial atonement. To the extent that this is an ethical matter for the presiding judge, outside of the control of the lawyer, speculation and suggestions regarding the likely or preferred response are largely outside the bounds of this Note. ${ }^{60}$ I do believe, however, that there are two powerful signals that the atoning lawyer communicates to the bench to encourage a just and truthful resolution. The first I have mentioned already: By "speaking truth to power" in a costly and unexpected way, and particularly by disclosing a proximate truth typically undervalued by her profession, the lawyer emphasizes to the judge the importance of the truth and the court's service of it. The second signal is more mundane but no less important. The lawyer's willingness both to disclose the perjury and to accept its penalty strongly suggests that her client is innocent-that is, that the factfinder has already reached the ultimate truth. The counsel for a guilty client found innocent is unlikely to stay in the courtroom any longer than she needs to.

subsequent to the acquittal defense counsel discloses his client's perjury. See U.S. CONST. amend. $\mathrm{V}$ ("No person shall ... be subject for the same offence to be twice put in jeopardy of life or limb ...."); Nix, 475 U.S. at 186 (Blackmun, J., concurring). Furthermore, under the doctrine of collateral estoppel, if the eventually disclosed perjury directly relates to one of the required elements of the offense, the factfinder's determination that that element has not been proven beyond a reasonable doubt operates to bar prosecution not only for the original substantive charge but the disclosed perjury as well. In effect, the jury's determination dictates not only the ultimate truth but also all subordinate proximate truths. See Ashe v. Swenson, 397 U.S. 436, 443 (1970) ("Collateral estoppel' ... stands for an extremely important principle in our adversary system of justice. It means simply that when an issue of ultimate fact has once been determined by a valid and final judgment, that issue cannot again be litigated between the same parties in any future lawsuit."); United States v. Nash, 447 F.2d 1382, 1385-86 (4th Cir. 1971) (applying the collateral estoppel doctrine to bar a subsequent perjury prosecution). But see United States v. Ruhbayan, 325 F.3d 197, 203 (4th Cir. 2003) (holding that the doctrine did not bar a subsequent perjury prosecution when the original trial jury had effectively ignored the defendant's perjured testimony).

60. That said, my hypothetical is not meaningfully coherent without a few words about the options available to the court in such a situation. Given the defendant's likely immunity from retrial, those options must address the perjury itself: A court may initiate proceedings against the lawyer for his involvement in the perjury or, with the consent of the state, a perjury prosecution of the defendant himself. In the scenario I have presented here, the disclosing defense counsel would offer to assume the penalty that would be imposed on his client were his client found guilty of perjury. For example, the federal perjury statute provides that convicted perjurers shall be "fined under this title or imprisoned not more than five years, or both." 18 U.S.C. $\S 1621$ (2000).

This particular arrangement has one significant benefit-the attorney does not need to claim he has "suborned" perjury, which he has not--and one significant drawback, namely that the judge needs to accept the attorney's vicarious sacrifice and, accordingly, the transfer of punishment from client to counsel. To my knowledge, there is no record of a court faced with this scenario, and it remains an open question whether the law would actually allow this. But courts are given broad leeway in punishing attorney misconduct-reprimands, fines, suspensions, prison terms-and it is not difficult to imagine some sort of ad hoc resolution. If nothing else, the attorney has violated the Model Rules by not taking "reasonable remedial measures" during trial, thus giving the judge a basis for which to impose on the attorney a punishment equivalent to that attributable to the client. See MODEL RULES OF PROF'L CONDUCT R. 3.3(a)(3) (2002). Such a solution would not be ideologically or schematically "clean," but it would accomplish most of the purposes and serve most of the values of a true substitutionary sacrifice. 


\section{VICARIOUS SACRIFICIAL ATONEMENT AND ASPIRATIONAL LEGAL ETHICS}

This lengthy treatment of a commonplace ethical dilemma is meant to introduce some of the goals, characteristics, and risks of an individual act of vicarious sacrificial atonement. Surely my recommendation seems hopelessly naive, but I do hope that it shines a slightly brighter light on some imperfections in the ethical framework within which such dilemmas arise. In any case, although the client perjury example provides perhaps the most frequent opportunity for a lawyer to make vicarious atonement for his client's misbehavior, my purpose in this Note is to sketch the contours of an aspirational ethical norm, not to detail an aspirational solution to one particular ethical dilemma. ${ }^{61}$

Perhaps not surprisingly, the aspirational ethical norm I propose is, like my "solution" to the client perjury dilemma, hopelessly naive. And I trust there is value in that. Holding up a proposal, however optimistic, as a goal toward which the existing system should strive and evolve serves an important purpose in structuring and channeling discussion regarding the relevant issue. Without such prodding,

[d]iscussions of legal ethics have a tendency to collapse into discussions of lawyer regulation. This happens when people assume that an ethical criticism of lawyering could be plausible only if it were susceptible to formulation and enforcement as a disciplinary rule.

This tendency should be resisted.... [I]t runs against the central current of the aspirational tradition of professional rhetoric. The term "ethics" has been applied to our subject precisely to suggest that it involves more than coercive rule enforcement. It is in part a collective effort to define the meaning of good lawyering and to mark out the road to personal satisfaction and social respect as a lawyer. $^{62}$

Thus fortified, I attempt in the remainder of this Note to flesh out the aspirational norm that encourages and supports individual acts of vicarious sacrificial atonement such as the one examined in the client perjury scenario above.

61. Unfortunately, opportunities abound for vicarious sacrificial atonement for client misdeeds. This is particularly true in criminal cases, although there are analogues in civil proceedings (particularly concerning discovery abuse) and even in less formal settings, such as when counsel for a recalcitrant client makes up a difference in settlement demands out of his own pocket. See THOMAS L. SHAFFER \& ROBERT F. COCHRAN, JR., LAWYERS, CLIENTS, AND MORAL RESPONSIBILITY 41 (1994).

62. SiMON, supra note 42, at 195. 
I hope that by this point in the argument it is clear what I mean when I say "an act of vicarious sacrificial atonement." The act itself might take many forms, but all would share the general characteristics described earlier and exemplified in my proposed solution to the client perjury hypothetical. My claim now is that these acts are only viable within the context of a broader aspirational norm that infiltrates and influences all aspects of the attorney-client relationship. That norm is best described by the values it hopes to serve, the goals at which it aims, and the barriers to its realization.

\section{A. The Values of Vicarious Sacrificial Atonement}

The groundwork for this discussion was laid in my earlier discussion of the inherent characteristics of vicarious sacrificial atonement: selflessness, compassion, and identification. These characteristics, together with the fundamental purpose and effect of the act itself, suggest two sets of values that acts of vicarious sacrificial atonement serve. ${ }^{63}$ The first set comprises abstract values: justice, truthfulness, and mercy, or what we might call "care." The values in the second set are more concrete: client victory, client autonomy, client rectitude, and client goodness. ${ }^{65}$

The core purpose and effect of vicarious sacrificial atonement-to put right a wrong-implicates the values of justice and truthfulness. These values are related but, as we saw in the client perjury hypothetical, not always coterminous. (That analytical exercise attempted to identify and eliminate the tension between the two by interposing a response that satisfied both.) One difference between the two values is the entity most closely associated with each. Justice is customarily seen as the responsibility of the state and its agents, while truthfulness is generally conceived of as a personal virtue. ${ }^{66}$ By positing both as values served by acts of vicarious sacrificial atonement, I wish to suggest that such acts bridge an important ethical divide between the moral obligations of the state and its agents and those of the individual acting as an independent moral unit. The performer of an act of vicarious sacrificial atonement is foremost an individual, not an officer of the court or even the member of a

63. Each set has been appropriated from Thomas Shaffer and Robert Cochran's insightful Lawyers, Clients, and Moral Responsibility, although they neither characterize nor apply the values in the way that I do here. See SHAFFER \& COCHRAN, supra note 61.

64. For useful background on the nature and operation of these three values in the context of the attorney-client relationship, see $i d$. at 62-92.

65. Id. at 3. The authors suggest that all analysis of attorney-client "moral issues" turns on the question of what the attorney wants for his client and list these four values as possible answers to that question.

66. I agree with Aristotle, Aquinas, and the many others who insist that justice is also an important personal virtue. I claim here only that justice is not the dominant concept in the dialogue or dynamic of interpersonal relationships. When someone "does right" by another person, she does a work of justice, but she is not likely to think of it in those terms. 
profession, although her act has consequences for both. The hallmark of this individuality is mercy, a value that transcends and even opposes the system in which the act takes place.

Mercy is also the third abstract value served by vicarious sacrificial atonement. Unlike justice and truthfulness, mercy is more closely related to the inherent characteristics of the act-selflessness, compassion, and identification-than to the core purpose and effect of atonement. Discussion of the role of mercy in criminal law, and particularly in sentencing, appears occasionally in the legal literature, ${ }^{67}$ but mercy's proponents and detractors disagree vigorously about both its moral and practical implications, and the idea has gained little traction in popular circles. I skirt this debate by framing mercy differently, as applying to the relationship between attorney and client rather than between criminal and state or victim. This mercy is best understood, as Thomas Shaffer and Robert Cochran appreciate, as an "ethic of care." "Isolation, oppression, pain, and suffering are seen as basic evils." 69 Applying that principle here, clients whose bad acts require atonement are truly in need of care, and, to be caring, the lawyer's response must be selfless, compassionate, and empathetic.

These values are admirable, but are also so universal as to risk being useless in resolving an actual ethical dilemma. They are important to mention insofar as they describe acts of vicarious sacrificial atonement as extensions of personal morality into the professional and civic spheres; to be viable in the prevailing ethical environment, however, those acts need to operate on terms that lawyers and clients can evaluate and apply. Fortunately, both these abstract principles and the inherent characteristics of vicarious sacrificial atonement serve a set of more concrete, clientoriented values.

The first, client victory, may not always be at issue, as when the client has committed a procedural infraction (such as missing a scheduled court hearing) for which his attorney makes atonement, but the justice-seeking nature of vicarious sacrificial atonement assures that that any meritorious substantive claim will be advocated and served. The client perjury hypothetical demonstrated that vicarious sacrificial atonement need not call for the sacrifice of client victory to some abstract notion of truth, although it may often require risking loss to reach both victory and a fuller satisfaction of the requirements of truthfulness.

67. See, e.g., Stephen P. Garvey, "As the Gentle Rain from Heaven": Mercy in Capital Sentencing, 81 CORNELL L. REV. 989 (1996); Eric L. Muller, The Virtue of Mercy in Criminal Sentencing, 24 SETON HALl L. REV. 288 (1993).

68. SHAFFER \& COCHRAN, supra note 61 , at 71 .

69. Id. (quoting OWEN FLANIGAN, VARIETIES OF MORAL PERSONALITY 203 (1991)). 
Client autonomy is the second concrete value, and is protected by the ex post facto nature of acts of vicarious sacrificial atonement. Although we hope that both ethical counseling and the lawyer's "threat" of vicarious sacrificial atonement will prevent misbehavior, the client should be permitted in the end to exercise his autonomous ability to misbehave. The lawyer should not interfere, for even anticipated misbehavior provides an opportunity for both lawyer and client to learn a beneficial moral lesson. ${ }^{70}$ Furthermore, the client remains free not to accept the lawyer's act of vicarious sacrificial atonement. Unlike the strong-arm tactics of paternalism, such acts are made from a position of weakness-they have no force apart from the willingness of both client and court to accept their efficacy and sufficiency.

If accepted, however, vicarious sacrificial atonement powerfully serves the third concrete value-client rectitude. A successful act of vicarious sacrificial atonement removes all traces of wrongdoing and restores the client to the position he occupied prior to his misdeed. ${ }^{71}$ It should not leave him unchanged, however, as the attorney-client relationship has been radically altered. No longer is the lawyer merely a collaborator, a joint venturer, a counselor, or even a friend. She has rendered herself a sacrifice, and is accordingly endowed with greater moral authority than her strictly professional role confers upon her.

Finally, should the attorney-client relationship continue subsequent to the act of vicarious sacrificial atonement, we should expect that the act, through the attorney who performed it, will serve the value of client goodness by encouraging in the client superior moral behavior to that which he practiced previously. I examine this potential benefit-a goal of the aspirational norm-more fully below, ${ }^{72}$ but only after a discussion of the two more fundamental goals that enable it.

\section{B. The Goals of Vicarious Sacrificial Atonement}

The primary purpose of an act of vicarious sacrificial atonement is, of course, to propitiate for a wrong or to repay a debt, thus eliminating both the need for further satisfaction and all memory of the transgression. These individual acts derive from, are supported by, and further propagate an aspirational norm of vicarious sacrificial atonement that has its own agenda for attorney-client relations. I asserted at the outset that acts of vicarious sacrificial atonement could benefit the legal profession in at least three

70. But see supra note 58 .

71. This is something that the traditional ethics of client counseling seems not to appreciate. For a discussion of an approach to counseling that more fully considers what should happen after the client has committed the bad act, see infra Subsection III.B.2.

72. See infra Subsection III.B.3. 
plausible and practical ways: by increasing the social and professional respect accorded to lawyers; by restoring client counseling as the focus of the attorney-client relationship; and by chilling client misbehavior, thereby strengthening the justice system for all players. I examine these goals in more detail now.

\section{Increasing Respect for Lawyers}

Unlike the other two goals of vicarious sacrificial atonement, increasing the level of social and professional respect accorded to lawyers is not directly related to the interests of the client. Still, it is not entirely self-centered. Although heightened respect would work wonders for the psychological and spiritual well-being of lawyers - an important concern of legal ethics-respect is also critically important to the quality of the attorney-client relationship. This is true both in the broadest view, as clients are drawn from the world of people with attitudes about lawyers, and within the narrow confines of a single representation, whether construed as an agency relationship (where respect reduces costs) or a more organic counseling relationship (where respect increases efficacy). I suggest that the establishment of an aspirational norm of vicarious sacrificial atonement, propagated and punctuated by individual acts of the same, would increase the esteem given to all lawyers. This newfound respect would improve not only the quality of lawyers' lives, but also the moral quality of the attorney-client relationship and its fruits-litigation, business dealings, and the many other tasks lawyers undertake for their clients.

It is both trite and untrue to say that lawyers get no respect. Although public sentiment varies widely-perhaps more widely than with regard to any other profession-it is on the whole more positive than the proliferation of lawyer jokes and media caricatures would suggest. Nonetheless, lawyers as a class labor under at least a weak presumption that their intelligence, effort, and training are employed not in the service of the law but in manipulation or evasion of it. This suspicion may be a self-fulfilling prophecy, as lawyers "live down" to the expectations of the society whose collective attitude necessarily colors how attorneys perceive themselves. But there are stronger influences on attorney behavior than simply public perception. The adversary system in which lawyers operate makes unique moral and ethical demands on its practitioners. In turn, the ways in which lawyers meet those demands influence the degree of respect accorded to them as individuals and as a professional class.

I suspect that most lawyers accept some version of David Luban's theory of role morality as a necessary and proper component of a functioning adversary system. Professor Luban contends (and I am simplifying here) that a person's moral obligations are defined, and her 
ethical decisions justified, in reference to the professional context that precipitates the obligation or decision: Broadly put, "[t]he social script tells us the role we are to perform, and our range of choices lies primarily in the manner in which we perform our role." ${ }^{, 73}$ As it applies to, say, criminal defense lawyers, the theory holds that "adversarial advocacy... [is] justified by powerful moral and political concerns in the criminal defense paradigm."74 Role morality thus enables what William Simon calls the "Dominant View" of American legal process" - that "[t]he duty of a lawyer, both to [the] client and to the legal system, is to represent [the] client zealously within the bounds of the law." "76 Certain personal qualities, attitudes, and responses that would be disparaged by common morality are valorized when employed in service of the client's aims. Although many commentators are suspicious of the implications of role morality and its contribution to the Dominant View, ${ }^{77}$ the very dominance of that view suggests that most practitioners have deeply internalized the adversarial ethic and its channeled morality.

One difficulty with role morality as applied in the Dominant View is that it makes for bad press. Its conclusions, even when internally consistent, often seem to the outsider immoral and unjustified. This should not surprise us. As Professor Simon writes, "The popular view that defense lawyers commonly get acquittals for guilty defendants is probably wrong, but it is a reasonable inference to draw from arguments that portray aggressive defense as a potent bulwark against the state." ${ }^{, 78}$ The problem is one of perspective. There are three reasons a layperson might see the departures of role morality as ethical underachievement rather than actions justified by role. First, lawyers are highly trained-ignorance is no defense. Second, lawyers occupy positions of considerable responsibility-immateriality is no defense. Third, lawyers operate explicitly in a field concerned with the regulation of human behavior-irrelevance is no defense.

There are valid objections to each of these arguments against role morality, but I will not address them here. Instead, I argue in the opposite direction, that the lawyer's role-incorporating her training, responsibility, and societal purpose-confers on her the potential for extraordinary moral impact and the obligation to use that potential to work moral good for both

73. DAVID LubaN, LAWYERS AND JUSTICE: AN ETHICAL STUDY 106 (1988).

74. Id. at 148.

75. SIMON, supra note 42 , at 7.

76. MODEL CODE OF PROF'L RESPONSIBILITY EC 7-1 (1980). Professor Simon translates this official formulation as follows: "[T]he lawyer must-or at least may-pursue any goal of the client through any arguably legal course of action and assert any non-frivolous legal claim." SIMON, supra note 42 , at 7.

77. See, e.g., SIMON, supra note 42, at 170-94 (arguing that role morality does not justify certain adversarial litigation strategies practiced by criminal defense attomeys and espoused by the Dominant View).

78. Id. at 193. 
her client and her community. As the earlier analysis of the client perjury hypothetical suggests, vicarious sacrificial atonement can accomplish both goals.

My argument for more rigorous moral obligations for lawyers owes much to Justice Louis Brandeis's belief in the "opportunity in the law," that "lawyers have the opportunity to make the law better by law reform activity, and to make their clients better by using their advisory role to awaken the client to the public dimension of their activities, to steer them in the direction of the public good."79 Justice Brandeis's view, however, esteems foremost the public interest and requires that lawyers first serve a common good. The norm of vicarious sacrificial atonement, on the other hand, is at heart a personal ethic that seeks to reach a broader audience from below rather than from above. Unlike what Professor Luban calls the "social-engineering mentality" ${ }^{\prime 80}$ of Justice Brandeis's thinking, vicarious sacrificial atonement esteems individual clients in the hopes that the synergistic effects of isolated acts of sacrifice will resound through the community to the ultimate benefit of all. The norm is based on a willingness to serve, not preside. ${ }^{81}$

Although the individual client is undoubtedly the focus of an act of vicarious sacrificial atonement, the ethical norm associated with such acts has important benefits for his lawyer's well-being and social status. One danger of the role morality expressed in the prevailing adversary system is its tendency to creep into the personal morality of individual lawyers. John Rawls describes this process as the acquisition of a "definite pattern of wants and aspirations" unique to a chosen profession. ${ }^{82}$ So an athlete might become aggressive and competitive off the playing field, a brain surgeon obsessive and wary outside the hospital. There is a certain chicken-and-egg dynamic at work here, but what is clear, and more to the point, is that at least a trace of whatever popular distaste attaches to lawyers as professionals follows them out of the office as well.

This phenomenon qualifies Montaigne's contention that "a man of honour is not accountable for the crimes or stupidities of his profession." ${ }^{\text {,3 }}$

79. LUBAN, supra note 73 , at 171 ; see also LOUIS D. BRANDEIS, The Opportunity in the Law, in BRANDEIS ON DEMOCRACY 52 (Philippa Sturm ed., 1995).

80. LUBAN, supra note 73, at 172.

81. Cf. Mark 10:45 (New International Version) ("[T]he Son of Man did not come to be served, but to serve, and to give his life as a ransom for many.").

82. RAWLS, supra note 32 , at 365 ; see also SHAFFER \& COCHRAN, supra note 61 , at $49-50$ (suggesting that a lawyer's adversarial role can influence him personally and make him "insensitive to moral issues"); Gerald Postema, Moral Responsibility in Professional Ethics, 55 N.Y.U. L. REV. 63, 77 (1980) ("To preserve his integrity, a lawyer must carefully distance himself from his activities.").

83. Michel de Montaigne, On Restraining Your Will, in THE COMPlete EsSays 1134 , 1144 (M.A. Screech ed. \& trans., 1993). But see GERALD J. POSTEMA, Self-Image, Integrity, and Professional Responsibility, in THE GOOD LAWYER: LAWYERS' ROLES AND LAWYERS' ETHICS 286, 291 (David Luban ed., 1983) ("The responsible person seeks to integrate roles, relations, 
Even if the honest lawyer-that is, one who is honest both away from and at her desk-is not morally culpable for the downward moral departures demanded by her adversarial role, she is responsible for those "vices" to the extent that her effectiveness as an advocate and her personal satisfaction are diminished by popular association of her own morality with the morality of her profession. By enacting and promoting a higher moral standard-one characterized by selflessness, compassion, and identification-acts of vicarious sacrificial atonement can operate within the adversary system to mitigate such adverse consequences.

\section{Restoring Client Counseling}

Just as the goal of increasing respect for attorneys operates in the shadow of the adversary system, the goal of restoring client counseling as the focus of the attorney-client relationship must be explored in relation to its primary stumbling block: a prevailing ethic of professional independence that limits the exposure lawyers have to the consequences of their clients' moral choices. ${ }^{84}$

One drawback of the ethic of professional independence is a limited conception of the scope and potential of client counseling. Most legal writing on client counseling is prospective-it focuses on ethical exchanges that take place between lawyer and client before the misdeed occurs. We saw a common instance of this in Professor Freedman's client perjury hypothetical: The client makes known to the lawyer his intention to commit an unethical act; the lawyer "advises" (the word used by both Freedman and the Model Rules) her client of the various prevailing legal and ethical duties that apply to one or another of them; the client listens to the advice, understands it, and proceeds to commit the unethical act anyway.

From any rational perspective, the client's commission of the unethical act must be seen as a failure of the counseling relationship, and the more strongly we assert the existence of such a relationship, the more apparent the failure becomes. This may explain the fullness and vigor with which prevailing ethical models excuse the individual lawyer from any fault. To do so requires a strong reliance on a choice-based theory of rights. ${ }^{85}$ The client has the autonomy to choose for good or for ill, and all his lawyer (and the legal ethicist) can do in the event of a wrong choice is throw up her hands. Clients will be clients, after all.

preferences, etc. into a coherent conception of self and the moral life, and where this is impossible seeks to abandon the role ... and if this fails, accepts responsibility for the failure.").

84. See infra Subsection III.C.2.

85. See SHAFFER WITH SHAFFER, supra note 14, at 17. 
Thomas Shaffer has written that choice-based ethics "has shown less interest than we might expect in how quandaries come about." ${ }^{, 86}$ As Professor Shaffer notes, moral dilemmas are currently seen as a problem for the lawyer to navigate rather than an opportunity for discourse with the client. ${ }^{87}$ I would add that choice-based ethical models, along with the approach to client counseling they imply, also have shown insufficient interest in what happens after the quandary or dilemma has been resolved incorrectly-that is, after the client has misbehaved.

Vicarious sacrificial atonement is intimately concerned with what happens after the bad act has been committed, and this concern is the key to a true and efficacious counseling relationship. I have already alluded to several aspects of the connection between acts of vicarious sacrificial atonement and the goal of client counseling, one of which is the importance to effective counseling of the moral authority with which the performer of the act is endowed. That authority derives in significant part from the professional and social esteem the client accords the lawyer, a phenomenon that reinforces the importance of increasing that esteem. Moral authority also emerges from the characteristics of identification, dominant before the act of atonement, and cohesion, dominant after the act, to bind the counselor to the client and increase the authenticity and power of her counsel.

Within an aspirational norm of vicarious sacrificial atonement, whatever moral authority the lawyer has with the client is employed toward the practice of mercy-what I am calling "care"-as the key value served by the counseling relationship. ${ }^{88}$ This value is both prospective and retrospective. Prior to the bad act, it seeks to intervene to spare the client the moral damage his misbehavior will wreak. Following the misdeed, it seeks to atone for that damage and to make whole both the client and the injured party.

Such an encompassing relationship survives even the client's rejection of his lawyer's counsel against the bad act. Through the anticipation and execution of acts of vicarious sacrificial atonement, the attorney-client relationship develops into something beyond a collaboration, beyond a joint venture, beyond even a friendship. It is in effect transformed from a contractual relationship to a covenantal one. ${ }^{89}$

86. $I d$.

87. See SHAFFER, supra note 14 , at 16.

88. See JOSEPH G. AllegReTtI, THE LAWYER's CALling: Christian FAITH AND LEGAL PRACTICE 100-04 (1996) (describing the different approaches to client counseling employed by lawyers adopting an ethic of care versus an ethic of rights).

89. See id. at 38-50. Like sacrifice, the idea of covenant is a religious concept that has acquired over the centuries an entire theology and doctrine too extensive to survey here. Covenants do, however, evidence several key characteristics that make them ideal models for a counseling relationship. Among other qualities, they are gratuitous, mutual, lasting, 


\section{Chilling Client Misbehavior}

The narrowest but perhaps most provocative goal of vicarious sacrificial atonement is the reduction of the overall level of client misbehavior during litigation. I assert that in addition to increasing the social and professional esteem accorded to lawyers and restoring the vitality of the client counseling relationship, the establishment of a norm of vicarious sacrificial atonement would prevent not only future bad acts by clients whose lawyers have previously atoned for them but also misdeeds by clients whose lawyers have not yet performed such acts but are members of a class of professionals known to do so.

This effect seems counterintuitive-how will removing the apparent costs of a particular behavior while maintaining its apparent benefits result in a reduction in the frequency of that behavior? I appreciate this economic intuition, and admit at the outset that chilling client misbehavior is perhaps the most aspirational goal in a Note full of the same. It relies wholly on the moral power inherent in acts of self-sacrifice, and reckons that power greater than the admittedly powerful self-interest of a client allowed to behave in a costless but advantageous way. ${ }^{90}$ Assuming the effect exists at all, the degree of ethical leverage exerted by those who offer themselves for others will vary with certain conditions, including the status of the offeror to the offeree and to the world at large. Accordingly, chilling client misbehavior is the ambitious but natural extension of the two goals discussed above.

The ability of lawyers to influence the ethical decisions of their clients is widely accepted even by those who disclaim any obligation (or even any right) for the lawyer to exercise that influence. Underlying the traditional argument against the mandatory disclosure of client perjury, for instance, is the contention that although clients do not have a right to behave badly, "lawyers functioning within the ... relationship can do more for sound morals than government can." I I happen to agree with this debatable

communitarian, and creative. They are also efficient-successful covenants do not require the monitoring, bonding, and other costs that hamper a standard agency relationship. There is usually at the outset a most solemn marker of the parties-a seal of blood, an act of sacrificial atonement-that binds the two sides together with such force that adherence to the mutual agreements of the covenant is assumed going forward. See generally DANIEL J. ELAZAR, COVENANT AND POLITY IN BIBLICAL ISRAEL: BIBLICAL FOUNDATIONS AND JEWISH EXPRESSIONS (1995) (surveying the development of the doctrine of covenant in a religious and political context).

90. There are probably published psychological studies that would support this calculus and probably those that would rebut it, but here I would like to depart from the standard practice of legal scholarship and appeal to the reader's own experience. If it supports my assertion, the point will be made with greater force than any citation could give it; if it does not, no amount of scholarship will change that fact.

91. See SHAFFE, supra note 14 , at 40 . The ability of lawyers to shape client decisions applies in corporate law as well as in litigation. See, e.g., SHAFFER WITH SHAFFER, supra note 14, 
empirical ordering, but note also that regardless of the relative efficacy of private and public regulation, the lax enforcement of standards for the disclosure of client perjury has failed to prevent its prevalence, perhaps the most common form of client misbehavior during litigation. ${ }^{92}$ The attorney-client relationship seems not to be operating at its full and considerable moral potential.

Vicarious sacrificial atonement has the ability to restore the moral efficacy of the attorney-client relationship without changing any of the prevailing ethical codes or official regulatory standards. Such acts are not obligatory and impose no enforceable duty on the lawyer faced with a misbehaving client. Instead, they rely on two important characteristics of vicarious sacrificial atonement: the ex ante process of identification between the lawyer and her client who is contemplating a bad act, and the ex post establishment of cohesion between the client and his lawyer who has just made atonement for him.

The "threat" prospectively to prevent client misbehavior. For this to happen, however, the client must know of, trust in, and appreciate his lawyer's background willingness to assume responsibility for her client's actions. The first requirement-that a client know of his lawyer's willingness to atone for his bad act-implicates the client counseling goal discussed earlier. Any act of vicarious sacrificial atonement must take place within the context of a healthy counseling relationship that both predates and survives the bad act. Such a relationship increases the likelihood both that the client will disclose to the lawyer his contemplation of the bad act and that the lawyer will have the opportunity to counsel fully against it.

The second requirement of a credible "threat" of vicarious sacrificial atonement is that the client trust in his lawyer's willingness to perform the atoning act. This requirement implicates the earlier goal of increasing respect and esteem for lawyers. The lawyer's threat is only viable if the client accords both her and her profession the type of respect associated with those who keep their promises and are serious about their moral commitments. I have already discussed the challenges to increasing respect for lawyers as a class; esteem for the individual lawyer will arise only from the substance of her dealings with her clients, and thus the lawyer's stated willingness to make atonement must follow and accord with behavior that evidences the values of selflessness and compassion..$^{94}$ Of course, nothing

at 214 (discussing anecdotal evidence that "business people are subject to moral influence from their lawyers").

92. See supra note 45.

93. Cf. Shaffer, supra note 14, at 95 (discussing the coercive power of the threat of abandonment).

94. The requirement of client trust also implies that the key barrier to the goal of chilling client behavior is the prospective systematic unwillingness to accept acts of vicarious sacrificial 
proves willingness to perform like actual performance, and a successful act of vicarious sacrificial atonement is the strongest evidence that the lawyer will serve the values it promotes. Although performance of the act implies that the client has misbehaved in a particular instance, its accomplishment adheres the attorney to her client, strengthens the credibility of the attorney's future threats, and increases the esteem due all lawyers to such a degree as will have significant positive influence on the efficacy of their counseling efforts and ultimately the moral quality of litigation experienced by all participants. In this way, acts of vicarious sacrificial atonement strive toward a more inclusive and complete understanding of justice.

The requirement that the client appreciate his lawyer's willingness to make vicarious sacrificial atonement demands more than simply locating and understanding her intention within the context of their prior and anticipated future dealings. The client and the lawyer must also identify with each other. This identification must include an understanding of each other's role in the instant dilemma, the considerations of right and wrong that inform the other's thinking, and the consequences to each other of the possible outcomes. But the most important dimension along which the lawyer must identify with her client is their mutual moral fallibility. Adopting a position of moral superiority encourages the one who is by insinuation morally inferior to compensate by shifting both his culpability and his punishment to the oppressor. The lawyer must be wary of such posturing, and affirm in the client their common membership in a community that often faces, and fails, difficult moral and ethical tests. This is a crucial point: The "moral power" inherent in self-sacrifice should not-must not-derive from the guilty feelings of the one whose punishment has been removed from him. That is, the costs of the client's misbehavior must be shifted fully to the attorney, not transmuted from legal or economic burdens to emotional or psychological ones.

A client may know of, trust in, and appreciate his lawyer's willingness to make vicarious sacrificial atonement and yet still commit the bad act. He may do so out of good motives or bad. The lawyer may want him to do so or be utterly dismayed at its occurrence. In the end, there is certainly the risk that clients will take advantage of vicarious sacrificial atonement. I believe that the characteristics and values of such acts are compelling enough to mitigate significantly that risk, but there is ultimately no rejoinder to the opposing view-vulnerability to exploitation is a position of weakness from which acts of vicarious sacrificial atonement present 
themselves. I do not think that such vulnerability lessens the importance of the acts or the larger norm; it might even increase it. ${ }^{95}$

Finally, since I suspect that those who have worked with actual clients are likely to be most skeptical of the viability of this last goal, I should reemphasize that it is just that-a goal, not a prediction. This also seems like an opportune time to begin a discussion of the various barriers to acts of vicarious sacrificial atonement.

\section{The Barriers to Vicarious Sacrificial Atonement}

I suggest that there are three principal barriers to acts of vicarious sacrificial atonement: the demands and expectations of the adversary process, the prevailing professional ethic of independence, and a systemwide unwillingness to acknowledge the sufficiency of sacrificial acts to atone for the wrong committed. The first two of these are ethical; the third is moral. Before tackling these arguments, however, let me briefly address two more abstract critiques-one from liberalism, the other from Liberalism.

The former insists first that no power should compel acts of vicarious systematic atonement and second that, absent such compulsion, no lawyer will ever attempt such acts. My response to the first assertion is enthusiastic agreement. The values of vicarious sacrificial atonement are obliterated by force, and such acts must be wholly, even if hesitantly, voluntary. The second assertion may be true, although history, religion, and domestic life suggest that the capacity for vicarious sacrificial atonement exists under certain circumstances, some of which may even involve lawyers.

The Liberal critique brands such acts paternalism, the bogeyman of relativists and law professors everywhere. ${ }^{96}$ But vicarious sacrificial atonement is not "the imposing of constraints on an individual's liberty for the purpose of promoting his or her own good. ${ }^{, 97}$ Instead it is the imposing of constraints on one's own liberty for the purpose of promoting the good

95. See infra Subsection III.C.4.

96. One scholar has memorably dubbed paternalism "the royal road to totalitarianism." Paul Roberts, Philosophy, Feinberg, Codification, and Consent: A Progress Report on English Experiences of Criminal Law Reform, 5 BUFF. CRIM. L. REV. 173, 228 (2001). But the classic waming comes, perhaps ironically, from Justice Brandeis: "Experience should teach us to be most on our guard to protect liberty when the government's purposes are beneficent. Men born to freedom are naturally alert to repel invasion of their liberty.... The greatest dangers to liberty lurk in insidious encroachment by men of zeal, well-meaning but without understanding." Olmstead v. United States, 277 U.S. 438, 479 (1928) (Brandeis, J., dissenting), overruled by Katz v. United States, 389 U.S. 347 (1967), and Berger v. New York, 388 U.S. 41 (1967). I have already noted the paternalistic overtones in Justice Brandeis's teaching on legal ethics. See supra note 79 and accompanying text.

97. David Luban, Paternalism and the Legal Profession, 1981 WIS. L. REV. 454, 461 (quoting Dennis Thompson, Paternalism, Medicine, and Public Policy, in ETHICS TEACHING IN HIGHER EDUCATION (D. Callahan \& S. Bok eds., 1980)). 
of the other. The paternalistic have nothing at stake; they act to better their own lot, with no risk of loss. Vicarious sacrificial atonement requires that one lose something of personal value in order that another might gain.

There is certainly more heft to these objections than I have disposed of here, ${ }^{98}$ but more concrete and more significant barriers present themselves.

\section{The Adversary Process}

No less a titan of the adversary process than Chief Justice Warren Burger once said:

The entire legal profession-lawyers, judges, law teachers-has become so mesmerized with the stimulation of the courtroom contest that we tend to forget that we ought to be healers-healers of conflicts. Doctors, in spite of astronomical medical costs, still retain a high degree of public confidence because they are perceived as healers. Should lawyers not be healers? Healers, not warriors? Healers, not procurers? Healers, not hired guns? ${ }^{99}$

98. Indeed, there are certainly more than just two abstract critiques. Another might be from economics, which suggests that, like any premium service, a market would arise around a lawyer's willingness to make vicarious sacrificial atonement for her clients. This is a perverse possibility, to be sure, but its likelihood is largely irrelevant to the conclusions of this Note. To see why, assume arguendo the establishment of a (necessarily) informal market, with clients contemplating perjury as buyers and lawyers willing to assume responsibility for their clients as sellers. Transactions would occur at the margin between the benefit of the "sacrifice" to the clients and the cost of the "punishment" to the lawyers, and fascinating legal scholarship would abound. But each compensated "sacrifice" would be nothing more than a quoted euphemism for a freemarket sale through which the central elements of the sacrificial dynamic had been monetized, negotiated, and exchanged. From this perspective, the argument from economics collapses into the argument from liberalism, since one way to compel someone is to pay her.

The existence of such a market, however, would undermine the norm of vicarious sacrificial atonement in at least one significant way: by establishing a presumption, difficult to rebut, that every lawyer who purports to make a sacrifice for her client makes a "sacrifice" instead. Any increase in the moral stature of lawyers would suffer accordingly, and those committed to the upkeep of that stature would be forced to expend the resources necessary to sustain it.

A final, related concern: Again assume arguendo (and this takes some doing) that the practice of vicarious sacrificial atonement in fact takes hold and individual lawyers begin to make such acts on behalf of their clients. The system permits them to do so and imposes on them the harsh but appropriate penalties otherwise attributable to their misbehaving clients. Despite having willingly accepted those penalties, the lawyers, having paid them, are naturally disinclined to do so again. A new class of lawyers thus has been formed: those who will screen prospective clients for ones who will not commit the sort of infractions for which the lawyer may atone. Accordingly, such clients - who deserve representation as good as that received by those who do not share their unfortunate tendencies-will not have full access to the legal resources they deserve. There is no adequate response to this concern other than to say that if it is ever borne out, the norm of vicarious sacrificial atonement already will have advanced very far and our profession will look very different indeed.

99. Warren Burger, The State of Justice, A.B.A. J., Apr. 1984, at 62, 66, quoted in ALLEGRETTI, supra note 88, at 69. 
I have already discussed at some length the role of the adversary process in undermining public confidence in and respect for lawyers, ${ }^{100}$ and further below $\mathrm{I}$ address some traits of the American justice system that render it hostile to acts of vicarious sacrificial atonement. ${ }^{101} \mathrm{I}$ wish here only to make the limited point that such acts are not inconsistent with advocacy or a vigorous adversarial process. William Stringfellow, a theologian and litigator, wrote that to be an advocate is to "undertake the cause of another (including causes deemed 'hopeless'), to intercede for the need of another (without evaluating it, but just because the need is apparent), to become vulnerable (even unto death) in the place of another." ${ }^{\text {"02 }} \mathrm{He}$ might as well have been describing vicarious sacrificial atonement. As I hope I have demonstrated, vicarious sacrificial atonement enacts an extreme loyalty to clients, a cohesion that transcends the lawyer's own priorities and selfinterest. Although embedded in our particular adversarial system are aspects of societal morality that may forestall acts of vicarious sacrificial atonement, there is nothing inherent in the adversarial process to discourage or preempt lawyers from making such sacrifices on behalf of their clients.

\section{The Ethic of Independence}

The developed codes of legal ethics erect a higher barrier to acts of vicarious sacrificial atonement than does the adversary process. The ABA's Model Code and Model Rules instantiate an ethic of moral independence and provide safeguards to ensure its protection. Through them the lawyer is insulated from both the immoral actions of her client and the common morality of the surrounding community. At the extreme, her connections to both parties are dangerously attenuated, and she can look only to herself and her colleagues to justify her ethical decisions. This arrangement-the product of selfishness and fear-discourages acts of vicarious sacrificial atonement.

Thomas Shaffer contends that the majority of the Model Code is focused on protecting the lawyer from corruption by the client, not directing the lawyer how best to serve the client's interests:

[T] he law on lawyers is now concerned with whether lawyers are obliged to refuse to do the wrong actions clients want them to do. The law on lawyers has been purged of concern for the goodness of

100. See supra Subsection III.B.1.

101. See infra Subsection III.C.3.

102. William Stringfellow, $A$ Lawyer's Work, 3 CHRISTIAN LEGAL SOC'Y Q. 17, 19 (1982), quoted in ALLEGRETTl, supra note 88, at 76. 
clients. It treats clients as threats, threats to the rights - that is, the isolation and independence - of lawyers. ${ }^{103}$

Professor Shaffer argues that prevailing legal ethics seeks first to protect the rights of lawyers and only then to promote the good of clients. ${ }^{104}$ Because distance is the best defense, the Model Code and Model Rules carve out for the lawyer a position of moral independence according to what Murray Schwartz calls the "Principle of Nonaccountability": "When acting as an advocate for a client... a lawyer is neither legally, professionally, nor morally accountable for the means used or the ends achieved." 105

The irony here is that the efforts of the ethical regime to protect the lawyer's independence cause her to lose her own subjectivity. She becomes an object acted upon by the client and the codes rather than a vital principal able to engage the client and to apply effectively the ethical leverage to which her training and status aspire. I do not deny that there are substantial professional benefits to the moral independence of lawyers, including the unfettered ability of the attorney to advocate his client's cause without fear of complicity. Such benefits, however, must be balanced against the dangers of moral independence. The first is what Professor Shaffer calls the "comfort of irresponsibility," 106 which leads to a dulling of the faculties required to dispense moral advice both to the client and to oneself. The second danger of moral independence is related: The lack of a strong external moral referent results in the promotion of an "ethic of honor and shame [that] says that the way to be good is to seek the approval of professional peers." 107 The establishment of this ethic completes the enclosure of the lawyer in a self-contained and insular moral world. Particularly given the danger that personal identity and professional roles will merge, ${ }^{108}$ such moral isolation not only weakens the attorney-client relationship but also risks personal insecurity and unhappiness.

Here vicarious sacrificial atonement has something to say to the lawyer and the codes. Unlike prevailing norms, vicarious sacrificial atonement does not seek to segment morality or to isolate legal ethics from other influences. Instead, it looks to diverse traditions for ethical guidance and imports values from outside the bounds of the profession. It regards both

103. SHAFFER WITH SHAFFER, supra note 14 , at 15 ; see also THOMAS L. SHAFFER, FAITH AND THE PROFESSIONS 275-76 (1987). Recall the Model Rules' fear of lawyer complicity in client perjury: "[T]he client could in effect coerce the lawyer into being a party to fraud on the court." MODEL RULES OF PROF'L CONDUCT R. $3.3 \mathrm{cmt} .11$ (2002).

104. See SHAFFER, supra note 14, at 13-20.

105. Murray L. Schwartz, The Professionalism and Accountability of Lawyers, 66 CAL. L. REV. 669, 673 (1978), quoted in LUBAN, supra note 73, at 7.

106. SHAFFER, supra note 13 , at 20.

107. Thomas L. Shaffer, On Thinking Theologically About Lawyers as Counselors, 42 FLA. L. REV. 467, 469 (1990).

108. See supra notes $82-83$ and accompanying text. 
attorney and client as moral actors, and encourages in the former an ethic of care motivated by selflessness, compassion, and identification. In its concern for justice and truthfulness, it regards the good of the community over the rights of the lawyer, and allows the lawyer through her sacrifice to participate in the achievement of that common good. ${ }^{109}$ She is a subject, not an object, a principal, not an agent, and in the act of vicarious sacrificial atonement both she and her client are reconciled to all.

\section{The System Itself}

At the outset of this Note, I asserted that our legal system is readily familiar with the concept of atonement. ${ }^{110}$ In every circumstance, however, atonement is sought from the perpetrator of the wrong, a perfectly reasonable arrangement but not the one I have presented here. In fact, we are loath to rupture the connection between debtor and repayment, criminal and punishment, and our refusal to do so stands as the greatest barrier to acts of vicarious sacrificial atonement. This refusal is essentially a moral stance, not an ethical one, and as such, the best approach seems to be to describe its contours briefly and let the reader compare what she knows of its virtues to the moral goods putatively achieved by vicarious sacrificial atonement.

There are three systemic entities whose prevailing views on the moral issues involved here-foremost among them the purpose and value of punishment - are essentially hostile toward vicarious sacrificial atonement: the courts, the public, and the injured. The views of the courts are the most consequential but also the most contingent, as a shift in public opinion can lead to the passage of new laws and regulations that judges and magistrates may be obliged to follow. ${ }^{111}$ In any case, the judge occupies the privileged position of independence: He is the caretaker of the justice system, and should act in its best interests. Recalling the client perjury hypothetical

109. Stephen Garvey's theory of atonement in criminal punishment relies directly on the interposition of "the community" into God's place in the traditional religious understanding of atonement. See Garvey, supra note 10, at 1810 . I agree that this is a valid-albeit weaker-secular analogue.

110. See supra note 7 and accompanying text.

111. Judges customarily have fairly broad discretion to manage the administration of their courtrooms. See, e.g., State v. McCahill, 811 A.2d 667, 678 (Conn. 2002) (striking down a statute prohibiting judges from granting bail to certain classes of criminal defendants on the grounds that the regulation "significantly interferes with the orderly functioning of the [court's] judicial role"). Accordingly, it should not surprise us to see some variety of responses to a proposed act of vicarious sacrificial atonement. It is likely that most would be hostile-judges as a class prize procedural regularity, and such an act as contemplated in the client perjury hypothetical above is nothing if not irregular. Irregularity is, I think, the first systemic barrier to vicarious sacrificial atonement, and it is likely to cause the greatest consternation in the judges who must adjust their expectations accordingly. This is not precisely a moral issue, but might in the end be the most significant determinant of judicial receptivity to acts of vicarious sacrificial atonement. 
discussed earlier, I hope I have made a persuasive case that the benefits to that system morally justify acceptance of the lawyer's act of vicarious sacrifice.

The views of the public are theoretically irrelevant to the viability of acts of vicarious sacrificial atonement, but ultimately important to the establishment of the broader norm. In the current climate, it seems unlikely that popular sentiment would welcome what would likely be perceived as the excusal of a defendant without sufficient penalty. Although nowhere in my advocacy of vicarious sacrificial atonement do I suggest that lawyers assume the criminal penalties attributable to their clients-only those penalties that arise during the adjudication of their crimes-the opprobrium given to criminal defendants for the wrong of which they have been accused is likely to follow them through its prosecution as well. ${ }^{12}$ This likelihood aside, the public at large arguably has little right to enforce the maintenance of the connection between an individual obligator and the satisfaction of his obligation, and has no recourse if other parties allow that connection to be broken by an act of vicarious sacrificial atonement. If this right inheres at all, it does so most securely in the entity that has suffered the injury resulting from the client's misbehavior.

I am acutely aware that throughout this Note I have focused on the attorney-client relationship and not on this injured third party, who may well be unwilling to accept the lawyer's act of vicarious sacrificial atonement. In some cases, the primary victim will be the presiding judge or court; in others, it may be a truthful but discredited witness or an adversarial civil litigant. In nearly all cases there will be a multitude of injured parties, some personal and some corporate, many harmed in nearly imperceptible ways, but all with both rights and goods that an act of vicarious sacrificial atonement would seek to honor and to serve. It is important to emphasize that such acts do not deny the wrongfulness of the client's infraction or the need for atonement. They are attempts not to sidestep the law or the punishment it requires, but rather to satisfy it fully. If the full satisfaction required by the law is then rendered, the injured party has no remaining basis for its claim except a sense of unfulfilled personal or corporate vengeance. ${ }^{113}$ I do not completely discount such bases (for

112. See Smith \& Montross, supra note 36, at 444 (noting that, when it comes to criminal defense, "[b]lame is a favorite pastime" and that "there is a universal call for individual accountability").

113. To see why, return briefly to the client perjury hypothetical and its injured party-the nearsighted witness whose testimony was discredited. Under the prevailing legal regime, disclosure of the defendant's lie following his acquittal might lead to his prosecution for perjury. In the best scenario for the discredited witness, that prosecution is successful and the defendant pays the just penalty for his lie. I assert that in such cases the witness has no remaining legal or moral claim against the perjurer. Those who agree with this conclusion are those who accept a system of justice in which penalties are measured and assessed with regard to the transgressor's actions and not his victim's sympathies. In such a system, the payment of a penalty by a 
example, in all cases a show of contrition from the misbehaving client is to be preferred over aloofness or denial), but suggest that the value of serving them will in most cases be significantly outweighed by the moral and ethical benefits of the act of vicarious sacrificial atonement.

There is, finally, a systemic barrier that is neither moral nor ethical and yet presents a serious challenge not only to the outcome of the earlier client perjury hypothetical but also to the norm of vicarious sacrificial atonement from which the outcome derives. ${ }^{114}$ The "truth-seeking" approach employed to reach that outcome assumed a priori that the attorney was certain of both the proximate and the ultimate truths of the scenario. Leaving aside for the moment questions of epistemology, it is clear that in making such an assumption the lawyer usurps the traditional-and proper-role of the factfinder. The coup declares the lawyer's disdain for the competence of the institutions designed to weigh and determine the truth and threatens to destabilize the system built around those same institutions.

This critique meets with both a theoretical and a practical response. The former refers back to my earlier discussion of attorneys as "officers of the court" and, as such, "officers of the truth." 15 The very word "officer" suggests that the lawyer's role is to serve the truth and to act as its agent. It also implies the sort of discretionary authority with regard to the truth that our system has in fact granted to attorneys, who are called on constantly to assess, frame, and present their clients' claims. In this way lawyers are themselves the earliest and most prolific of all factfinders. Although their findings are not legal "fact" until reached by a judge or jury, that provisional status in no way prevails upon the relation of those findings to reality.

But theoretical justification for this lawyerly role fails unless the lawyers themselves are not only generally competent to discharge it but also confident in their assessment of a given client's particular claims-that is, of reality. This underscores an important practical constraint on acts of vicarious sacrificial atonement, namely, that their propriety is highly contingent on the circumstances surrounding the decision to perform them. I have mentioned already that such acts lose their vitality when they are conipelled; they likewise lose their validity when they are contrived. Many different factual scenarios and client relationships may accommodate acts

transgressor is sufficient to discharge his debt; for better or worse, once the verdict is reached, the victim is no longer legally relevant. Without making any value claims for that arrangement, I note only its logical corollary-the imposition of an equivalent penalty on a legitimate substitute satisfies all claims to the same extent as it would were it imposed on the transgressor himself.

114. Although the following discussion implicates the broader norm of vicarious sacrificial atonement, it is tailored to the client perjury context. Questions of "truth" are not as pressing in the event of procedural infractions such as refusals to make discovery or failures to appear.

115. See supra notes $54-56$ and accompanying text. 
of vicarious sacrificial atonement, but in no case should such acts be performed without careful consideration of their purpose and effect.

\section{Failure}

Acts of vicarious sacrificial atonement may fail, for all of the reasons described above and many more. ${ }^{116}$ In fact, absent substantial change in the attitudes and practices that motivate the prevailing justice system, both individual acts and the establishment of a broader norm are certain to fail. But even certain failure should not preclude effort. There is a value beyond efficacy, and there is virtue in defeat.

Judge James Edwin Horton, Jr. understood this. ${ }^{117}$ He understood that granting a new trial to Haywood Patterson, one of the famed "Scottsboro Boys" tried for capital rape in Alabama in 1933, would end his career as an elected judge. He said as much to those who asked. He understood also that his action would have no effect on the ultimate disposition of $\mathrm{Mr}$. Patterson's case-Patterson would be retried by a different judge and found guilty. There were legal reasons not to grant the defendant's motion, but there were more powerful moral reasons to grant it, and so he did.

What Judge Horton did was an act of vicarious sacrificial atonement. Not for Haywood Patterson, who had done nothing to require it, but for a corrupt and racist system of justice which-like a client-had enriched the judge and to which-like a client-he had sworn allegiance. His act of atonement evidenced selflessness, compassion, and an identification with the wrongful system. It expressed justice, truthfulness, and a mercy that is best expressed through care.

Judge Horton was no saint; he was instead, as Thomas Shaffer says, "like any person of his time and place, walk[ing] fearfully in a dark night." similar image:

[T]he way, the real way, from the Creation to the Kingdom is trod not on the surface of success, but in the deep of failure. The real work, from the biblical point of view, is the late-recorded, the

116. See Garvey, supra note 10 , at $1846-58$ (discussing the many ways atonement can fail in the criminal justice context).

117. The definitive account of Judge Horton and the Scottsboro case is DAN T. CARTER, SCOTTSBORO: A TRAGEDY OF THE AMERICAN SOUTH (rev. ed. 1979). For a thorough ethical analysis of Horton's actions in the case, see SHAFFER, supra note 14, at 144-52.

118. SHAFFER, supra note 14 , at 147. 
unrecorded, the anonymous work. The real work is done in the shadow, in the quiver. ${ }^{19}$

In the end, each of Judge Horton's expectations came to pass: He was defeated in the next election, and Haywood Patterson was found guilty in a subsequent trial. The Alabama courts continued in their discrimination against and mistreatment of African-American criminal defendants. But there is value and virtue in the judge's act. Its worth lies not in its immediate success, but in its persistence through the deep of failure.

\section{CONCLUSION}

The suggestions and implications of this Note are strange. They contradict some of the most basic assumptions about our justice system and subvert some of its highest goals. They may well be wrong, or dangerous, and as such they are presented to individual readers to consider carefully and decide for themselves.

But there is the decision, and then there is its application. I can agree, as I have so often in this discussion, with Professor Shaffer when he says that "[t]he aim of moral life with patients, students, or clients ... is to serve in such a way that the person served will himself become a servant-that he will himself be moved to love, to good works, to the company of those who serve." ${ }^{20}$ I can believe that vicarious sacrificial atonement is a powerful means to accomplish that goal. But the qualities such acts require of me-selflessness, compassion, and identification; justice, truthfulness, and care- too often seem beyond my ability or even my inclination to achieve.

I am encouraged in this by the words of the medieval English mystic Walter Hilton: "I feel . . . so far in true feeling from that that I speak and have spoken, that I can nought else but cry mercy, and desire after [it] as I may." 221 Such aspiration is a familiar position for ethicists, but perhaps a more demanding one than is usually adopted by lawyers facing ethical issues. Compare Charles Fried's casual treatment of a classic nonlegal dilemma, that "[o]ne who provides an expensive education for his own children surely cannot be blamed because he does not use these resources to alleviate famine or to save lives in some distant land," 122 with the full casuistical analysis of the same problem conducted by ethicist Garth Hallett

119. MARTIN BUBER, Biblical Leadership, in ISRAEL AND THE WORLD: ESSAYS IN A TIME OF CRISIS 119, 133 (Syracuse Univ. Press 1997) (1948), quoted in SHAFFER, supra note 103 , at 39.

120. SHAFFER, supra note 103, at 65.

121. Walter Hilton, The SCale of Perfection 34 (Evelyn Underhill ed., John $M$. Watkins 1923) (1375).

122. Charles Fried, The Lawyer as Friend: The Moral Foundations of the Lawyer-Client Relation, 85 YALE L.J. 1060, 1066 (1976). 
in his book Priorities and Christian Ethics. Professor Hallett concludes that everyone should prioritize the starving or threatened over his own wellbeing, but those who lack the ethical wherewithal to do so should not be rebuked for their shortcoming. ${ }^{123}$ The difference between the two approaches is subtle but critical. For the lawyer, the allocation of blame too often answers the question of how to act. The obligations of prevailing legal ethics are defined in the negative- "What must I do to avoid censure?"124 For the moral ethicist, the question is more likely to be "What can I do to work the greatest good?"

I have cast Professor Fried as a straw man, to be sure. His comment is a passing remark used to support a wholly different ethical argument. Professor Hallet, on the other hand, reaches his conclusion only after meticulous examination of the problem from first principles. But perhaps we should apply such strict scrutiny to the practices of our own profession as well. At the very least, we should approach the challenges of legal ethics from a greater distance, striving toward answers that satisfy our broadest moral aspirations for law and lawyering. Such struggle is itself a sacrifice-of our comfort and time, and perhaps dearer things besides. I hope I have shown it would not be in vain. 